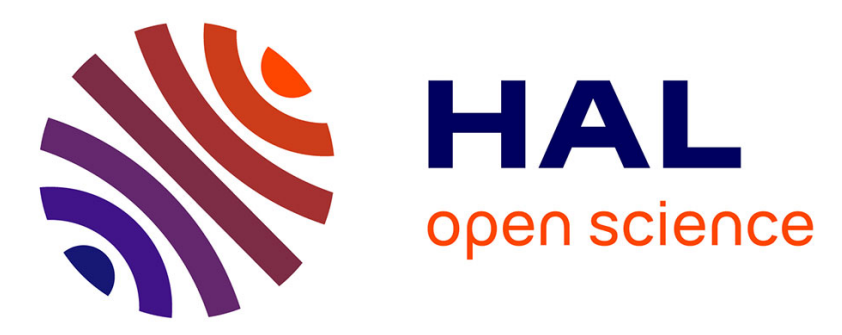

\title{
Towards rapid assessments of tree species diversity and structure in fragmented tropical forests: A review of perspectives offered by remotely-sensed and field-based data
}

\author{
Elias Ganivet, Mark Bloomberg
}

\section{To cite this version:}

Elias Ganivet, Mark Bloomberg. Towards rapid assessments of tree species diversity and structure in fragmented tropical forests: A review of perspectives offered by remotely-sensed and field-based data.

Forest Ecology and Management, 2019. hal-02880281

\section{HAL Id: hal-02880281 \\ https://hal.science/hal-02880281}

Submitted on 24 Jun 2020

HAL is a multi-disciplinary open access archive for the deposit and dissemination of scientific research documents, whether they are published or not. The documents may come from teaching and research institutions in France or abroad, or from public or private research centers.
L'archive ouverte pluridisciplinaire HAL, est destinée au dépôt et à la diffusion de documents scientifiques de niveau recherche, publiés ou non, émanant des établissements d'enseignement et de recherche français ou étrangers, des laboratoires publics ou privés. 


\title{
Towards rapid assessments of tree species diversity and structure in fragmented tropical forests: A review of perspectives offered by remotely-sensed and field-based data
}

\author{
Elias Ganivet ${ }^{1 *}$ and Mark Bloomberg ${ }^{1}$ \\ ${ }^{1}$ Department of Land Management and Systems, Faculty of Agribusiness and Commerce, Lincoln University,
} Lincoln, New Zealand.

* Corresponding author: ganivet.elias@gmail.com (orcid.org/0000-0002-8617-4188)

Citation: Ganivet E, Bloomberg M (2019) Towards rapid assessments of tree species diversity and structure in fragmented tropical forests: A review of perspectives offered by remotely-sensed and field-based data. Forest Ecology and Management, 432:40-53.

\begin{abstract}
With forest fragmentation continuing in many parts of the tropics, it is likely that fragmented forests will become the rule for most remaining global tropical forests in the next decades. In this context, there is a need for practical tools to assess and monitor fragmented forests if we are to conserve tree species diversity as much as possible. Several methods, either using (1) field-based or (2) remote-sensing approaches could be used to achieve this goal. This paper aims at providing a state-of-the-art review of both approaches in order to make recommendations for rapid and cost-effective assessments of tree species diversity and forest structure, with specific applications in studies of fragmented tropical forests. Overall both methods have pros and cons, depending on the type of data needed to address the research objectives and the quantity of resources available. We suggest combining the use of both field-based and remotely-sensed methods as they can be complementary. Remote-sensing data should be used to predict and map the tree species diversity and stand structure at regional scales, while field-inventories provide accurate information at local scales and allow validation of remotelysensed data. For field-inventories, we recommend the use of small (e.g. $20 \times 50 \mathrm{~m}$ ) plots with a $10 \mathrm{~cm} \mathrm{DBH}$ minimum measurement. In terms of remotely-sensed techniques, if funding is sufficient, airborne imagery seems the best regarding the quality of information (i.e. hyperspectral and hyperspatial imagery, LiDAR). If funding is limited, a cost-effective alternative providing reasonably accurate estimates would be the use of high-resolution satellite imagery such as Worldview. Ultimately, for studies where data accessible for free is the only possible option, we recommend the use of Sentinel-2, although it is relatively coarser in terms of quality. However, further research needs to be done to validate these approaches in fragmented tropical forests.
\end{abstract}


Keywords : Airborne imagery; Biodiversity; Forest fragmentation; Forest inventory; Satellite imagery; Tree species richness.

\section{Introduction}

Tropical rainforests are recognized for hosting a significant proportion of global biodiversity (Gaston 2000; Myers et al. 2000) and their conservation constitutes a major challenge (Koh and Sodhi 2010). Over the last five decades, increases in logging, agriculture and urban growth have led to significant losses of tropical forest (Houghton 1994; Lewis et al. 2015; Rosa et al. 2016) resulting in unprecedented fragmentation of this habitat (Laurance and Bierregaard 1997; Groombridge and Jenkins 2000; Koh and Wilcove 2008; Peres et al. 2010). A recent study revealed that $70 \%$ of remaining global forests are within $1 \mathrm{~km}$ of the forest's edge, subject to the degrading effects of fragmentation (Haddad et al. 2015). Global patterns of tropical forest fragmentation predict large increases in the total number of forest remnants in the future (by a factor of up to 33 over the next 50 years), as well as a decrease in their size (Taubert et al. 2018). With fragmentation continuing in many parts of the tropics, fragmentation might become the rule for most of the remaining global tropical forests in the next decades. Alroy (2017) reported that habitat disturbances have already led to a loss of about $30 \%$ of tree species in tropical forests. In this context, tropical forests urgently need to be monitored and closely managed if we are to conserve tree species diversity as much as possible.

Besides the direct loss of diversity caused by habitat reduction, fragmentation affects tree communities through impacts of edge-effects on the remaining fragments and increases in isolation which limits connections between them (see Fahrig 2003; Harper et al. 2005; Ewers and Didham 2006; Laurance 2008; Heinken and Weber 2013). In addition, because forest remnants are more accessible than continuous forests, after fragmentation, they are often exposed to human-induced disturbances such as illegal timber harvesting and land-clearance by small-scale farmers (Hamer et al. 1997; Fahrig 2003). Finally, due to their long lifespans, tree species are affected by fragmentation through slow long-term processes that lead to time-delayed species extinctions (Helm et al. 2006; Vellend et al. 2006; Metzger et al. 2009; Krauss et al. 2010); a process known as "extinction debt" (Tilman et al. 1994). All these factors combined together make it very difficult to estimate the real impact of fragmentation on tree communities over long time periods.

As noted by Kangas and Maltamo (2006), "All decision-making requires information. In forestry, this information is acquired by means of forest inventories, systems for measuring the extent, quantity and condition of forests." In this context, forest managers, as well as policy makers, have a need for practical forest inventory 
tools to assess and to monitor trends for biodiversity in fragmented tropical forests, thus providing information in support of management or intervention plans. While criteria and indicators for fragmented tropical forests may vary according to policy objectives (e.g. sustainable timber harvesting, carbon sequestration, maintenance of biodiversity at an ecosystem or landscape level, conservation of rare, endangered or valuable species), all are underpinned by information gained from forest inventories.

Although substantial efforts have been made by researchers over the last decades, the composition and structure of large areas of tropical forests remain poorly studied (Foster et al. 1998; Feeley and Silman 2011), thereby making forest management decisions difficult in many countries. This is even more relevant in fragmented tropical forests, considering that while most ecological studies have focused on undisturbed tropical forests, research has also highlighted possible conservation values of disturbed or fragmented tropical forests (e.g. Turner and Corlett 1996; Baynes et al. 2016). In classical field-based methods, much of the time and resources necessary to inventory sites are used for travel, which makes time spent in the field extremely valuable (Baraloto et al. 2012). Thus, a rapid inventory method providing information on both biodiversity (i.e. number of species) and forest structure would represent a major tool to improve our ability to plan for management and conservation of fragmented forests. Along with several methods using field-based approaches, the last decades have also seen increasing development of technologies using remote-sensing that could be used to achieve this goal.

Many studies have been published regarding rapid assessment of tree species diversity and forest structure based on field inventories (e.g. Higgins et al. 2004; Jayakumar et al. 2011; Baraloto et al. 2012; Arellano et al. 2016). Although several studies and reviews also exist about the potential of remote-sensing for forest inventories (e.g. Nagendra 2001; Chambers et al. 2007; Gillespie et al. 2008; Fassnacht et al. 2016; Lausch et al. 2016), only a few have addressed an overview of these technologies for assessments of both taxonomic and structural diversity at the same time (Lausch et al. 2016; Mulatu et al. 2017). In addition, to our knowledge very few studies have properly reviewed and compared the possibilities offered by field-based and remotely-sensed approaches at the same time (e.g. Bustamante et al. 2016). Even though this was attempted by Jayakumar et al. (2011), when this review was published they concluded that remote-sensing technologies needed more development and research. More importantly, while these studies were focused on undisturbed forests, to our knowledge no study has addressed what is best suited to highly-disturbed fragmented forests. In that context, this paper aims at providing a state-of-the-art review of both field-based and remotely-sensed approaches in order to make recommendations for rapid and cost-effective assessments of tree species diversity and forest structure, with specific applications in studies of fragmented tropical forests. 
Studies in fragmented tropical forests have several requirements. Forest fragmentation has usually been described as a non-random process and the configuration and shape of remaining fragments are often influenced by environmental factors such as soil type, topography or wetness (Turner 1989; Laurance 2008; Ibanez et al. 2017). Therefore, most forest remnants present a high variability of sizes and shapes, especially over regional scales (Ranta et al. 1998; Hill and Curran 2003; Ibanez et al. 2017), which is a problem for both field-based and remotely-sensed techniques. In contrast, most studies in contiguous tropical forests do not have to deal with this type of problem and, for example, allow implementation of very large survey plots of up to 50 ha (e.g. Lee et al. 2002). Recently, Taubert et al. (2018) reported that varying patterns of local deforestation (assessed from global data on forest cover) produced intriguingly similar patterns of tropical forest fragmentation at the continental scale. In this study, mean (median) sizes of global tropical forest fragments were 17, 13 and 13 ha for the Americas, Africa and Asia-Australia respectively, and are expected to decrease in future (Taubert et al. 2018). Forest fragments also presented very similar fractal dimension and perimeter scaling in the three continents. In their study at a landscape scale, even smaller fragment sizes were reported by Ibanez et al. (2017). Forest fragments presented irregular shapes and had sizes ranging from 0.1 to 54.6 ha with a median size of only 1.6 ha. Assessment techniques should thus also be able to deal with such small sizes of forest fragments.

Finally, another important requirement is the geographic area covered by an assessment. Although the geographic area of a study usually depends on both research objectives and resource availability, fragmented landscapes could theoretically be studied on scales from a few thousand hectares (e.g. Baynes et al. 2016; Ibanez et al. 2017) up to the total of tropical forest areas at the continental scale (940, 577 and 391 Mha for Americas, Africa and Asia-Australia respectively (Taubert et al. 2018)). Assessment methods addressing the future of fragmented tropical forests should thus deal with wide ranges in the assessment scale, and in the shape and size of fragments, while also being affordable. This is particularly important since most of this topic concerns developing countries where limited funding may only allow studies on a restricted scale.

\section{Field-based inventory methods}

Over the last decades, studies of tree species diversity in tropical forests have been increasingly standardized in order to allow comparison among research groups (Condit 1995; Condit et al. 2002; Malhi et al. 2002; Arellano et al. 2016). Some of the field-based inventory methods commonly used have been summarized in Table 1 . 
Table 1 : Examples of field-based inventory methods commonly used to assess tree species diversity and structure in tropical forests worldwide. Field effort is based on calculations from Baraloto et al. (2012) and Arellano et al. (2016). *: the five plot methods compared in the study from Baraloto et al. (2012). DBH: diameter at breast height.

\begin{tabular}{|c|c|c|c|c|c|c|c|}
\hline Method & Shape & $\begin{array}{c}\text { Area covered } \\
\text { (ha) }\end{array}$ & $\begin{array}{c}\text { Area inventoried } \\
\text { (ha) }\end{array}$ & $\begin{array}{l}\mathrm{DBH} \text { min } \\
(\mathrm{cm})\end{array}$ & Permanent & $\begin{array}{c}\text { Field effort } \\
\text { (person-days) }\end{array}$ & References \\
\hline Gentry Plot* & $\begin{array}{l}2 \times 50 \mathrm{~m} \\
\text { transects }\end{array}$ & 2 & 0.1 & 2.5 & No & 7 & $\begin{array}{c}\text { Boyle (1996); Phillips et } \\
\text { al. }(2003 a, b)\end{array}$ \\
\hline Whittaker Plot* & $20 \times 50 \mathrm{~m}$ & 0.1 & 0.1 & 2.5 & No & 7 & Campbell et al. (2002) \\
\hline $\begin{array}{l}\text { Modified Gentry } \\
\text { Plot* }\end{array}$ & $\begin{array}{l}10 \times 50 \mathrm{~m} \\
\text { transects }\end{array}$ & 2 & 0.5 & Variable & No & 8 & Baraloto et al. (2011) \\
\hline 0.5 ha Plot* & $50 \times 100 \mathrm{~m}$ & 0.5 & 0.5 & 2.5 & Yes & 15 & Baraloto et al. (2012) \\
\hline 1 ha Plot* & $100 \times 100 \mathrm{~m}$ & 1 & 1 & 10 & Yes & 25 & FAO (1981) \\
\hline Circular Plot & $30 \mathrm{~m}$ radius & 0.28 & 0.28 & 10 & Yes & 5 & Asner et al. (2010) \\
\hline 20-50 ha Plot & $\begin{array}{l}500 \times 500 \mathrm{~m} \text { to } \\
1000 \times 500 \mathrm{~m}\end{array}$ & Up to 52 & Up to 50 & 1 & Yes & $>500$ & Condit (1995) \\
\hline 0.1 ha Plot & $20 \times 50 \mathrm{~m}$ & 0.1 & 0.1 & 2.5 & No & $5-20$ & Arellano et al. (2016) \\
\hline
\end{tabular}

Overall, all field-based inventory methods have pros and cons and the most appropriate largely depends on (1) the quantity of resources available and (2) the type of data needed to address the research objectives. However, for specific applications in fragmented forests studies, several important aspects need to be considered. Firstly, an important decision is whether the plots need to be permanent or not. Permanent plots have considerable advantages for studies of forest dynamics and tree-species demographic rates. However, because individual trees need to be tagged and spatially located within permanently marked plots, they require a significant amount of time and effort to establish and monitor (Arellano et al. 2016). Temporary plots, on the other hand, do not require tagging and mapping of individual trees or permanent plot delineations, and each individual tree is only measured once. Since the objective in fragmented forests studies is to gather basic information on forest structure and composition over large areas, time- and cost-effective temporary plots are likely to be more suitable.

Considering the variety of methods found in the literature, including circular/square/rectangular plots or transects (see Table 1), other important aspects are both the size and the shape of the plots. Initially recommended by the Food and Agriculture Organization (FAO 1981), one of the most widespread field-based forest inventory methods is the 1-ha square plot (e.g. Phillips et al. 2009; Stropp et al. 2009). However, because of aggregative 
patterns and rare species in tropical forests, recent studies have suggested this approach is not the most appropriate to measure species diversity (Phillips et al. 2003b). This illustrates how the area inventoried vs the area covered is important in inventories of tropical forests. In Gentry plots for example, the inventoried area is only 0.1 ha. However, because this plot method is composed by ten $2 \times 50 \mathrm{~m}$ transects randomly dispersed within 2 ha (covered area), it allows assessment of more rare species than would be allowed by contiguous plots of similar size. Recently, after contrasting five of the plot methods presented in Table 1, Baraloto et al. (2012) recommended the use of 0.5 -ha modified Gentry plots for rapid inventories. Modified Gentry plots were the most efficient at providing accurate estimates (i.e. smaller coefficient of variation) of both tree diversity and above ground biomass over other methods.

On the other hand, according to Arellano et al. (2016), a problem with Gentry plots is that they are spread samples, and therefore diversity measures are affected by both alpha-diversity (local diversity recorded in a single transect) and beta-diversity on the 2-ha scale (the difference between each transect). Thus, although this method is useful for rapidly gaining a good understanding of a site's gamma-diversity, results can be unclear when looking at inter-sample comparisons to measure beta-diversity at larger scales (Anderson et al. 2011; Tuomisto 2011). For that reason, Arellano et al. (2016) recommended the use of contiguous $20 \times 50 \mathrm{~m}$ plots as standard protocol for woody plant inventories and soil characterization in tropical forests, since their installation is also relatively time- and cost-effective.

On the other hand, while recommendations of both Baraloto et al. (2012) and Arellano et al. (2016) were based on undisturbed forests; to our knowledge no published studies have addressed which plot shape is best suited to highly-disturbed fragmented forests. Two recent studies used either transects or circular plots (10 m radius) to extensively inventory trees in fragmented forests of the southern Philippines and New Caledonia respectively (Baynes et al. 2016; Ibanez et al. 2017). However, in both studies no comparison was made with other methods so we do not know if one is more time- and cost-effective than the other. Circular plots are widely regarded as difficult to demarcate in the dense understory of tropical forests (Alder and Synnott 1992), which makes them less suitable for rapid assessment of tree diversity. Only a few researchers continue to use them, mostly for calibration of remote-sensing estimates of above ground biomass or species diversity (e.g., Asner et al. 2010; Mauya et al. 2015; Schäfer et al. 2016).

Another major choice in fragmented forest studies is the size of the plot, since it needs to fit within most forest remnants in the area of interest. Considering the patchy distribution and the typically small size of forest 
fragments (global mean size of about 15 ha, Taubert et al. 2018), large (20-50 ha) plots are obviously completely unsuited. In addition, the irregularity of forest fragment shapes leads to higher edge-area ratio than for fragments with smoother and more regular shapes. For example, a 4-ha fragment may be a very thin and long strip following a river corridor in which a large plot would be impossible to locate. Therefore, because the modified Gentry plots recommended by Baraloto et al. (2012) have a dispersed spatial arrangement within a 2-ha area, we suggest fragmented forests are more likely to present sizes and shapes unsuitable for this type of plot. The 1-ha square plots are also likely to be unsuited for the same reason and thus, if we want to cover many forest remnants, smaller size plots might be more relevant.

Apart from the need to locate plots within small and variably-shaped fragments, the other key issue relating to the choice of plot size is its relationship with inventory cost and statistical power. Smaller plots take less time to install and measure, allowing more plots to be inventoried for a given financial or resource budget. However, smaller plots have a higher between-plot variance, and this must be traded-off against the plot cost in order to identify an optimal plot size (Evans and Viengkham 2001). The optimal plot size will be one where the desired statistical power (expressed as either a desired precision of the sample mean or ability to test a hypothesis of interest) is achieved for the least overall cost. For example, Grussu et al. (2015) re-analysed data from existing 1ha permanent sample plots in logged and unlogged forests in Papua New Guinea, in order to evaluate the optimal plot size for efficiently achieving estimates of tree species richness and carbon stocks. The original 1-ha plots were not found to be efficient, and optimum plot sizes for estimating tree species richness were 0.08 and 0.2 ha in unlogged and logged forests respectively. The larger optimum plot size in the logged forests was attributed to the greater within-plot variation in logged forests due to the presence of open harvesting coupes.

The last aspect to be considered in the choice of the inventory method is the minimum diameter for recording. While some methods start with a minimum diameter of 1 or $2.5 \mathrm{~cm} \mathrm{DBH}$, other methods start at $10 \mathrm{~cm} \mathrm{DBH} \mathrm{(see}$ Table 1). Small trees (from 1 to $10 \mathrm{~cm}$ ) are of particular interest as they provide information about both tree species regeneration and species that are not likely to grow into larger size classes. Baraloto et al. (2012) demonstrated well how this choice of minimum diameter can influence results and that smaller minimum diameters always provide better results. In this study, the relative ratio of overall richness between communities with a minimum diameter of $10 \mathrm{~cm}$ vs $2.5 \mathrm{~cm}$ was about $80 \%$. Unfortunately, because resources are usually limited a trade-off must be made between the amount of information collected and its cost. Thus, a minimum 
diameter of $10 \mathrm{~cm}$ seems more suited for time- and cost-effective assessments, allowing coverage of more forest remnants in the same amount of time.

\section{Remotely-sensed inventory methods}

Over the last decades, remote-sensing investigations have resulted in new ecological insights for tropical forests. Chambers et al. (2007) categorized them in three major research areas: (1) ecosystem process and forest function, (2) forest structure and species composition, and (3) land-use and land-cover change. Our review investigates techniques used in the second of these research areas. To our knowledge, no study has used remotesensing techniques specifically for assessment of tree species diversity and forest structure in fragmented tropical forests. Thus, most of the available techniques will be described using various examples from literature and their applicability for studies in fragmented forests will be discussed later. Techniques for assessment of (1) species composition and (2) forest structure will be presented in the next two sections.

\subsection{Forest species composition}

Assessing biodiversity from remote-sensing data has been well-researched over the last two decades (Nagendra 2001; Turner et al. 2003; Rocchini et al. 2010; Nagendra et al. 2013; Kuenzer et al. 2014; Pettorelli et al. 2014; Asner 2015). Three general approaches have been distinguished for assessment of species diversity and distribution using remote-sensing data (Nagendra 2001; Kerr and Ostrovsky 2003; Strand et al. 2007; Lausch et al. 2016): (1) habitat or ecosystem mapping, (2) direct mapping of individual plants and species, and (3) modeling of relationships between remotely-sensed data and species diversity and distribution patterns. Earlier studies mainly used high-resolution aerial photographs to identify vegetation classes such as forest type or individual plants to the species level (Gillespie et al. 2008). Recent research has focused on the use of airborne or satellite imagery at different spatial and spectral resolutions. Examples of remote-sensing techniques recently used for assessment of species composition have been summarized in Table 2.

Habitat or ecosystems mapping is usually based on medium resolution multispectral data from satellite imagery such as Terra-ASTER, Landsat-TM/ETM+ or Sentinel-2 (Nagendra et al. 2013; Kuenzer et al. 2014; Corbane et al. 2015). Such imagery can also be used for predicting species diversity by extracting measures of spectral entropy (Gillespie et al. 2009; Hernández-Stefanoni and Dupuy 2007; Rocchini et al. 2010; Hernández-Stefanoni et al. 2011; Maeda et al. 2014). Mapping of individual plants (i.e. tree species identification) on the other hand, is regarded as needing higher spatial and spectral resolutions than those offered by medium resolution satellite data 
(Turner et al. 2003; Gillespie et al. 2008). With medium resolutions of a few tens of meters, a single pixel often encompasses numerous individual trees, sometimes even crossing habitat boundaries (Small 2004; Nagendra and Rocchini 2008). With each pixel corresponding to a mixed field signature averaged across several objects, this necessarily leads to losses of information about species diversity and forest structure. 
Table 2 : Examples of remote-sensing methods used for assessment of plant species diversity sorted in increasing order of spatial resolution. Costs for satellite imagery can be found in http://www.landinfo.com. Exact costs for airborne methods depend on the sampling area: larger-area projects are more cost-effective than those in small areas. For example, Asner et al. (2010) reported a cost of less than 0.08USD/ha for a 4.3 million ha analysis using the CAO LiDAR. PAN $=$ panchromatic band. UAS = unmanned aerial systems.

\begin{tabular}{|c|c|c|c|c|c|c|c|}
\hline Types & Spatial resolution & $\begin{array}{l}\text { No of } \\
\text { bands }\end{array}$ & Sensors & \begin{tabular}{|c|} 
Spectral \\
resolution $(\mathrm{nm})$
\end{tabular} & Costs & Examples of use & References \\
\hline \multirow{2}{*}{ Satellite } & \multirow{2}{*}{$\begin{array}{c}30 \mathrm{~m} \\
(15 \mathrm{~m} \text { PAN band })\end{array}$} & \multirow{2}{*}{9} & \multirow{2}{*}{$\begin{array}{l}\text { Landsat (TM, } \\
\text { ETM+) }\end{array}$} & \multirow{2}{*}{$435-1384$} & \multirow{2}{*}{ Free } & Modeling diversity in a tropical forest & $\begin{array}{c}\text { Hernández-Stefanoni } \\
\text { et al. (2012) }\end{array}$ \\
\hline & & & & & & $\begin{array}{l}\text { Assessing tree species diversity in temperate } \\
\text { forest }\end{array}$ & Arekhi et al. (2017) \\
\hline \multirow{2}{*}{ Satellite } & \multirow{2}{*}{$\begin{array}{l}10 \mathrm{~m} \text { (4 bands) } \\
20 \mathrm{~m} \text { (7 bands) } \\
60 \mathrm{~m} \text { (2 bands })\end{array}$} & \multirow{2}{*}{13} & \multirow{2}{*}{ Sentinel-2 } & \multirow{2}{*}{$443-2190$} & \multirow{2}{*}{ Free } & $\begin{array}{c}\text { Crop and tree species classification in central } \\
\text { Europe }\end{array}$ & Immitzer et al. (2016) \\
\hline & & & & & & $\begin{array}{l}\text { Discrimination of tropical forest types, } \\
\text { dominant species and functional guilds }\end{array}$ & Laurin et al. (2016) \\
\hline Satellite & $\begin{array}{c}4 \mathrm{~m} \\
(1 \mathrm{~m} \text { PAN band })\end{array}$ & 5 & IKONOS & $450-900$ & $\begin{array}{c}\text { Medium } \\
\left(10 \mathrm{USD} / \mathrm{km}^{2}\right)\end{array}$ & $\begin{array}{c}\text { Mapping invasive wetland species in Hudson } \\
\text { River }\end{array}$ & Laba et al. (2010) \\
\hline Airborne & $3.3-3.6 \mathrm{~m}$ & 224 & $\begin{array}{c}\text { AVIRIS } \\
\text { Spectrometer }\end{array}$ & $366-2510$ & High & $\begin{array}{l}\text { Hyperspectral remote-sensing of canopy } \\
\text { biodiversity in Hawaiian lowland rainforests }\end{array}$ & Carlson et al. (2007) \\
\hline Satellite & $\begin{array}{c}2.8 \mathrm{~m} \\
(0.6 \mathrm{~m} \text { PAN band })\end{array}$ & 5 & Quickbird & $450-900$ & $\begin{array}{c}\text { Medium } \\
\left(17.5 \mathrm{USD} / \mathrm{km}^{2}\right)\end{array}$ & $\begin{array}{c}\text { Detection of invasive species in southwest } \\
\text { Texas }\end{array}$ & Everitt et al. (2005) \\
\hline \multirow[b]{2}{*}{ Satellite } & \multirow[b]{2}{*}{$2 \mathrm{~m}$} & \multirow[b]{2}{*}{8} & \multirow[b]{2}{*}{ WorldView } & \multirow[b]{2}{*}{$400-1040$} & \multirow{2}{*}{$\begin{array}{c}\text { Medium } \\
\left(17.5 \mathrm{USD} / \mathrm{km}^{2}\right)\end{array}$} & Detection of invasive species in Australia & Robinson et al. (2016) \\
\hline & & & & & & $\begin{array}{c}\text { Tree species classification in temperate } \\
\text { Austrian forest }\end{array}$ & Immitzer et al. (2012) \\
\hline
\end{tabular}




\begin{tabular}{|c|c|c|c|c|c|c|c|}
\hline & & & & & & $\begin{array}{l}\text { Tree species mapping in humid subtropical } \\
\text { forest }\end{array}$ & Cho et al. (2015) \\
\hline Satellite & $\begin{array}{c}2 \mathrm{~m} \\
(0.5 \mathrm{~m} \text { PAN band })\end{array}$ & 5 & GeoEye & $450-920$ & $\begin{array}{c}\text { Medium } \\
\left(17.5 \mathrm{USD} / \mathrm{km}^{2}\right)\end{array}$ & $\begin{array}{l}\text { Assessment of population structure of Acacia } \\
\text { tortilis }\end{array}$ & $\begin{array}{l}\text { van Coillie et al. } \\
\text { (2016) }\end{array}$ \\
\hline Airborne & $2 \mathrm{~m}$ & 114 & $\begin{array}{c}\text { Goddard's LiDAR } \\
+ \text { Hyperspectral (G- } \\
\text { LiHT) imager }\end{array}$ & $407-1007$ & $\begin{array}{l}\text { Free. Cover limited } \\
\text { to some parts of the } \\
\text { USA }\end{array}$ & Mapping plant richness in a forest landscape & $\begin{array}{l}\text { Hakkenberg et al. } \\
\qquad \text { (2018) }\end{array}$ \\
\hline \multirow[b]{2}{*}{ Airborne } & \multirow[b]{2}{*}{$1.12 \mathrm{~m}$} & \multirow[b]{2}{*}{72} & \multirow{2}{*}{$\begin{array}{c}\text { CAO-Alpha HiFIS } \\
\text { spectrometer + } \\
\text { LiDAR }\end{array}$} & \multirow[b]{2}{*}{$367-1058$} & \multirow[b]{2}{*}{ High } & Mapping tree species composition in savannas & Cho et al. (2012) \\
\hline & & & & & & Tree species mapping in Panama tropical forest & Baldeck et al. (2015) \\
\hline Airborne & $1 \mathrm{~m}$ & 129 & $\begin{array}{l}\text { AisaEAGLE } \\
\text { imaging } \\
\text { spectrometer }\end{array}$ & $400-1000$ & High & Mapping tree species diversity of tropical forest & Schäfer et al. (2016) \\
\hline \multirow{3}{*}{ UAS } & \multirow{3}{*}{$0.05 \mathrm{~m}$} & \multirow{3}{*}{$\begin{array}{c}1 \\
(\mathrm{RGB})\end{array}$} & \multirow{3}{*}{ Photograph camera } & \multirow{3}{*}{$450-690$} & \multirow{3}{*}{$\begin{array}{c}\text { Low } \\
(<2000 \text { USD })\end{array}$} & Identification of tropical Ecuadorian trees & Peck et al. (2012) \\
\hline & & & & & & Mapping tropical forest diversity using a drone & Koh and Wich (2012) \\
\hline & & & & & & Classification of riparian forest species & Michez et al. (2016) \\
\hline
\end{tabular}


Hyperspatial (i.e. high spatial resolution) satellite (e.g. IKONOS, Quickbird, Worldview-2) or aerial imagery seem better suited for biodiversity mapping as a pixel resolution of only a few meters corresponds well to the size of individual tree crowns (Read et al. 2003; Wulder et al. 2004). Yet, it has also been argued that while hyperspatial data are well suited to locating features within an image, they might be less suited for species identification (Nagendra and Rocchini 2008; Nagendra et al. 2010). At high resolution, problems arise from increases in variability of signatures among pixels covering the same individual tree (Avena et al. 1999; Song and Woodcock 2002; Rocchini and Vannini 2010). This can happen for instance when pixels are smaller than tree crowns and cover different parts such as bark, sunlit leaves, shaded leaves and even sometimes forest floor (Gougeon 1995; Meyera et al. 1996). However, more recently, Baldeck et al. (2015) argued that within-crown spectral variability does not prevent species classification of pixels and that hyperspatial data are suitable for both accurate feature location and species identification. They hypothesized that this disparity could be caused by recent developments in classification methods, with latter methods able to accommodate complex withinclass variations.

Hyperspectral (i.e. high spectral resolution) imagery, on the other hand, is an even more important tool for tree species identification, reducing the need for extremely high spatial resolutions (and its possible corresponding noise) as it allows recording of spectral signatures down to sub-pixel levels (He et al. 2011). Using a series of contiguous bands covering narrow spectral ranges, it is possible to record information related to a range of plant properties such as water content, leaf pigment and chemical composition (Curran 1989; Martin and Aber 1997; Townsend et al. 2008). Recent studies in tropical forests in Sarawak (Asner et al. 2012a), Amazonia (Asner and Martin 2011), Hawaii (Asner and Martin 2009), and Australia (Asner et al. 2009) have shown that, based on their structural and biochemical properties, tree species often have unique spectral signatures. Variability in hyperspectral information can thus be used for discriminating tree species at a landscape scale, even in complex ecosystems such as tropical forests (Cochrane 2000; Clark et al. 2005). Nowadays, both aerial and satellite sensors enable detection of subtle differences in reflectance among species which has led to advancements in tree species identification (Clark and Roberts 2012; Laurin et al. 2014).

So far, most studies using high-resolution imagery to identify individual tree species come from areas which have only a few dominant species, such as temperate/boreal forests (e.g. Immitzer et al. 2012), savannas (e.g. Colgan et al. 2012) or mangroves (e.g. Wang et al. 2004). Although already challenging when there are a few species, this task presents even greater challenges in tropical forests where the species richness of trees $>10 \mathrm{~cm}$ in diameter may exceed 300 species per ha (Valencia et al. 1994), along with higher canopy complexity and 
frequent cloud cover. The mapping of individual tree species is usually based on a supervised classification that requires spectral training and validation data on each target species (e.g. Baldeck and Asner 2013). However, considering the high variety of tree species in tropical forests, with many of them rare (especially in fragmented forests), training and validation data would be practically impossible to obtain for each species. Instead, Baldeck et al. (2015) used single-class classification methods to identify individuals of three focal canopy species amongst a diverse tropical forest on Barro Colorado Island. Nevertheless, although efficient due to the low amount of training data required, these methods only allow a focus on a limited number of species, which make them unsuitable for assessment of species diversity in fragmented tropical forests.

An alternative for mapping species diversity would be the use of unsupervised classification as it does not require any prior information on the species. The main idea of this approach is not to directly relate spectral species to biological species, but rather to approximate the diversity of species observed in the field from the spectral species distribution (Carlson et al. 2007; Asner and Martin 2011; Féret and Asner 2014). According to the spectral variation hypothesis (SVH) (Palmer et al. 2002), the spectral variation of a site can be related to its ecosystem heterogeneity. Since greater heterogeneity allows a higher number of species to coexist (Huggett 1995; Wilson 2000), this hypothesis has potential predictive power for species diversity (Rocchini 2007; Oldeland et al. 2010; Rocchini et al. 2010). This reasoning has particularly been used by studies that aimed at predicting species diversity based on medium resolution satellite imagery (e.g. Rocchini et al. 2010; HernándezStefanoni et al. 2011; Maeda et al. 2014). The mapping of species diversity based on unsupervised classification might have similarities with the SVH as the clustering result can be interpreted as a measure of spectral heterogeneity (Medina et al. 2013; Féret and Asner 2014). However, while the SVH suggests that spectral variation arises from heterogeneity of habitats, when using high spatial resolution imagery, spectral variation is assumed to arise from heterogeneity in canopy-level tree species composition (Féret and Asner 2014).

Although unsupervised classification has potential for direct prediction of tree species diversity from highresolution imaging spectroscopy data, so far very few studies have attempted to apply this approach. In their study, Baldeck and Asner (2013) and Féret and Asner (2014) suggested methods using pixel-based classification results. More recently, Schäfer et al. (2016) developed a method using object-based (i.e. crown-based) classification. Earlier studies have used transformation of individual tree crown delineations (from remotelysensed imagery) into objects in order to improve species discrimination (Lucas et al. 2008; Féret and Asner 2012). This approach has the advantage that reflectance characteristics are averaged over entire tree crowns, which decreases within-species spectral variation (Blaschke et al. 2014). However, despite the relatively good 
estimates of species richness provided by this approach $\left(R^{2}=0.5\right.$ in Schäfer et al. (2016)), they focused on small areas (around $100 \mathrm{ha}$ ). We suggest that individual tree crown delineation could be more difficult to apply to larger areas such those used in fragmented forest studies. For studies at landscape or regional scales, pixel-based classification, although being not as accurate, might be easier to implement.

Another promising candidate to improve tree biodiversity mapping is the combination of hyperspectral and light detection and ranging (LiDAR) remote-sensing (Dalponte et al. 2008; Holmgren et al. 2008; Jones et al. 2010; Dinuls et al. 2012; Féret and Asner 2012; Leutner et al. 2012; Ghosh et al. 2014). It is expected that hyperspectral imagery coupled with LiDAR data may complement each other and improve species discrimination by detection of more subtle species-specific spectral and structural properties (Féret and Asner 2012). While hyperspectral data provides detailed surface reflectance characteristics related to leaf chemistry, LiDAR provides detailed three-dimensional positional information related to foliage density and crown architecture (Leutner et al. 2012). However, despite the promising possibilities offered by this approach, to date few studies have used it as the method is relatively recent.

Finally, the last decade has seen increasing development of innovative technologies using unmanned aerial systems (UAS). These new technologies have been described as an effective alternative for cost-effective assessments of forest biodiversity using very high spatial $(<0.1 \mathrm{~m})$ and temporal resolution (Koh and Wich 2012). Several studies have taken advantages of these two characteristics in a broad range of forest topics such as tree and forest characterization (Lisein et al. 2013; Zarco-Tejada et al. 2014), forest species composition (Dunford et al. 2009; Peck et al. 2012; Gini et al. 2014; Michez et al. 2016) and forest biodiversity assessment (Getzin et al. 2012). References on assessment of tree species biodiversity using UAS imagery are still rare in the literature and concern mostly temperate regions (e.g. Getzin et al. 2012). Moreover, while most of the recent studies from aerial or satellite imagery used hyperspectral data for tree species identification, most studies based on UAS only used hyperspatial data from high-resolution photograph cameras. However, nowadays even spectral camera systems (e.g. Saari et al. 2011; Hruska et al. 2012; Zarco-Tejada et al. 2013; Franklin et al. 2017), as well as LiDAR systems (e.g. Lin et al. 2011; Wallace et al. 2012), may be mounted on UAS to obtain both hyperspectral imagery and three-dimensional forest scans. Although to our knowledge no study has used this low-cost approach in highly diverse tropical forests so far, it constitutes a promising candidate method for future studies on tree diversity, especially in developing countries where satellite and airborne sensors can be prohibitively costly and inaccessible for researchers. 


\section{$\underline{3.2 \text { Forest structure }}$}

Assessing forest stand structure from remote-sensing data has also been well-researched for several decades (Næsset 2002; Clark et al. 2011; Hou et al. 2011; Wulder et al. 2012; Henry et al. 2015; Lu et al. 2016). It can be categorized into three different approaches, all related to each other: (1) detecting and quantifying forest aboveground biomass (AGB), (2) assessing vertical vegetation structure and structural complexity, and (3) predicting horizontal forest structural stand parameters (e.g. mean diameter, basal area, stem density). Table 3 summarizes examples of remotely-sensed techniques recently used in the context of these three approaches.

Over the last decades, studies using remote-sensing technologies to assess forest structure have mostly focused on quantification of AGB in relation to the monitoring of global carbon fluxes. Medium spatial resolution data from satellite imagery, such as Landsat-TM, have been the most widely used remotely-sensed systems for biomass estimations (Main-Knorn et al. 2013; Latifi et al. 2015; Lausch et al. 2016) as they provide good compromises regarding data-availability, data-processing and detail level. Broadband indices derived from such imagery, such as the Normalized Difference Vegetation Index (NDVI), have been used for a long time in tropical forest studies as a correlate with biomass (Sader et al. 1989; Steininger 2000; Foody et al. 2003). 
Table 3 : Examples of remote-sensing methods used for assessment of forest structure sorted in increasing order of spatial resolution. Costs for satellite imagery can be found in http://www.landinfo.com. Exact costs for airborne methods depend on the sampling area: larger-area projects are more cost-effective than those in small-areas. PAN = panchromatic band. UAS = unmanned aerial system.

\begin{tabular}{|c|c|c|c|c|c|c|c|}
\hline Types & Spatial resolution & $\begin{array}{l}\text { No of } \\
\text { bands }\end{array}$ & Sensors & $\begin{array}{c}\text { Spectral } \\
\text { resolution }(\mathrm{nm})\end{array}$ & Costs & Examples of use & References \\
\hline \multirow{2}{*}{ Satellite } & \multirow{2}{*}{$\begin{array}{c}30 \mathrm{~m} \\
(15 \mathrm{~m} \text { PAN band })\end{array}$} & \multirow{2}{*}{9} & \multirow{2}{*}{$\begin{array}{l}\text { Landsat (TM, } \\
\text { ETM+) }\end{array}$} & \multirow{2}{*}{$435-1384$} & \multirow{2}{*}{ Free } & Modeling biomass in Brazil Atlantic forest & Barbosa et al. (2014) \\
\hline & & & & & & Mapping carbon stock in the Amazon & Asner et al. (2010) \\
\hline Airborne & $5 \mathrm{~m}$ & - & CAO-Alpha LiDAR & - & High & Tropical forest carbon mapping & Asner et al. (2012b) \\
\hline \multirow{2}{*}{ Satellite } & \multirow{2}{*}{$\begin{array}{c}4 \mathrm{~m} \\
(1 \mathrm{~m} \text { PAN band })\end{array}$} & \multirow{2}{*}{5} & \multirow{2}{*}{ IKONOS } & \multirow{2}{*}{$450-900$} & \multirow{2}{*}{$\begin{array}{c}\text { Medium } \\
\left(10 \mathrm{USD} / \mathrm{km}^{2}\right)\end{array}$} & $\begin{array}{c}\text { Estimating canopy structure in an Amazon } \\
\text { forest }\end{array}$ & Asner et al. (2002) \\
\hline & & & & & & $\begin{array}{c}\text { Landscape and regional variations in tropical } \\
\text { forest canopy structure }\end{array}$ & $\begin{array}{l}\text { Malhi and Román- } \\
\text { Cuesta (2008) }\end{array}$ \\
\hline Satellite & $\begin{array}{c}2.8 \mathrm{~m} \\
(0.6 \mathrm{~m} \text { PAN band })\end{array}$ & 5 & Quickbird & $450-900$ & $\begin{array}{c}\text { Medium } \\
\left(17.5 \mathrm{USD} / \mathrm{km}^{2}\right)\end{array}$ & \multirow{2}{*}{$\begin{array}{c}\text { Mapping aboveground biomass of African } \\
\text { forest mosaics }\end{array}$} & \multirow{2}{*}{ Bastin et al. (2014) } \\
\hline Satellite & $\begin{array}{c}2 \mathrm{~m} \\
(0.5 \mathrm{~m} \text { PAN band })\end{array}$ & 5 & GeoEye & $450-920$ & $\begin{array}{c}\text { Medium } \\
\left(17.5 \mathrm{USD} / \mathrm{km}^{2}\right)\end{array}$ & & \\
\hline Satellite & $\begin{array}{c}2 \mathrm{~m} \\
(0.5 \mathrm{~m} \text { PAN band })\end{array}$ & 5 & Pléiades & $430-950$ & $\begin{array}{c}\text { Medium } \\
\left(12.5 \mathrm{USD} / \mathrm{km}^{2}\right)\end{array}$ & Prediction of forest structure in New Caledonia & $\begin{array}{l}\text { Blanchard et al. } \\
\text { (2015) }\end{array}$ \\
\hline Satellite & $2 \mathrm{~m}$ & $\begin{array}{c}1 \\
(\mathrm{RGB})\end{array}$ & Google Earth image & $450-690$ & Free & Assessing aboveground tropical forest biomass & Ploton et al. (2012) \\
\hline Airborne & $2 \mathrm{~m}$ & 480 & $\begin{array}{c}\text { CAO-AToMS } \\
\text { (spectrometer + } \\
\text { LiDAR) }\end{array}$ & $252-2648$ & High & Landscape-scale changes in forest structure & Asner et al. (2014) \\
\hline Airborne & $1.6 \mathrm{~m}$ & 210 & FLI-MAP LiDAR + & $400-2500$ & High & Estimation of tropical rainforest aboveground & Clark et al. (2011) \\
\hline
\end{tabular}




\begin{tabular}{|l|c|c|c|c|c|c|c|}
\hline & & & $\begin{array}{c}\text { HYDUCE } \\
\text { spectrometer }\end{array}$ & & biomass & \\
\hline Airborne & $1 \mathrm{~m}$ & $\begin{array}{c}1 \\
(\mathrm{RGB})\end{array}$ & Photograph camera & $450-690$ & High & Predicting tropical forest stand structure & Couteron et al. (2005) \\
\hline UAS & $0.05 \mathrm{~m}$ & $\begin{array}{c}1 \\
(\mathrm{RGB})\end{array}$ & Photograph camera & $450-690$ & $\begin{array}{c}\text { Low } \\
(<2000 \mathrm{USD})\end{array}$ & $\begin{array}{c}\text { Forest structure estimation in temperate } \\
\text { coniferous forest }\end{array}$ & Ota et al. (2017) \\
\cline { 4 - 7 } & & & & & $\begin{array}{c}\text { Kiomass estimation in a tropical woodland } \\
(2016)\end{array}$ \\
\hline
\end{tabular}


Laser scanning methods such as LiDAR have also emerged as a promising technology for estimating forest height, volume and AGB in boreal, temperate and tropical forests (Drake et al. 2002; Lefsky et al. 2002a; Clark et al. 2004; Hyyppä et al. 2008). Able to provide direct descriptors of forest structure including tree height, crown size, and tree density (Heurich and Thoma 2008; Bergen et al. 2009), LiDAR sensors are of particular interest for the estimation of forest biomass and carbon stocks (Corona and Fattorini 2008; Steinmann et al. 2013). Spaceborne systems, such as the Geoscience Laser Altimeter System (GLAS) sensor or the Global Ecosystem Dynamics Investigation (GEDI) sensor (scheduled for launch in 2018 on the International Space Station, Stavros et al. 2017), usually provide large foot-print LiDAR data (i.e. 1-80 m) (Lefsky et al. 2002b; Lefsky et al. 2007). In contrast, airborne systems are able to provide LiDAR data down to a very small foot-print (i.e. $0.25-0.60 \mathrm{~m}$ ) (Lefsky et al. 2002b). It is also expected that LiDAR data coupled with hyperspectral imagery may complement each other and improve estimates of biomass and other forest structure properties, especially if hyperspectral imagery provides canopy species, phenology and biochemical information (Asner et al. 2007; Koetz et al., 2007; Asner et al. 2008). The most recent methodological improvements for estimation of AGB involve remote-sensing data at a high spatial resolution such those provided by satellites (e.g. Pléiades, World View, IKONOS, Quickbird) (Bastin et al. 2014) or aerial photographs (Kachamba et al. 2016). Ploton et al. (2012) even used free high-resolution images from Google Earth to assess AGB.

Numerous modeling approaches have been proposed in order to convert the physical signal (i.e. canopy texture or LiDAR waveform) into forest structural parameters such as AGB (Asner et al. 2012b; Barbier et al. 2012; Vincent et al. 2014). The underlying theory of these approaches is that, considering the relationship between tree height and tree diameter (Feldpausch et al. 2010), trees visible in the canopy usually constitute most of the AGB of tropical forests (Clark et al. 2001; Rutishauser et al. 2010; Slik et al. 2013). Forest structure could thus be directly predicted from the physical signal observed from the sky. While LiDAR-derived AGB estimates are usually based on forest height metrics (e.g. Asner et al. 2010; Saatchi et al. 2011, Baccini et al. 2012), those based on approaches using canopy texture from high resolution imagery come from the horizontal distribution of crown sizes in the canopy (Bastin et al. 2014). For example, several studies report that high AGB was related to stands exhibiting coarser canopy texture on high-resolution imagery (Proisy et al. 2007; Ploton et al. 2012; Blanchard et al. 2015).

Despite the importance of mapping AGB (i.e. carbon stocks), studies of fragmented tropical forest also need information on classical horizontal structural variables such those measured in field inventories: stem density, 
basal area and mean diameter. Although to date, fewer studies have investigated the relationship between canopy features and these variables, the underlying theory remains the same as for the AGB. For example, using texture indices provided by the Fourier transform textural ordination (FOTO) on high-resolution images, Couteron et al. (2005) were able to obtain a very good correlation with these stand parameters ( $\mathrm{R}^{2}$ value up to 0.8 and 0.71 for tree density and diameter of the tree of mean basal area respectively). Drake et al. (2002) also found strong correlations between large foot-print LiDAR waveform metrics (i.e. Height of Median Energy of the waveform: HOME) and AGB, basal area and mean diameter ( $\mathrm{R}^{2}$ values up to $0.93,0.72$ and 0.93 respectively). Finally, as for diversity assessments, recent studies on forest structure have seen increasing development of technologies using UAS which brings promising perspectives (e.g. Ota et al. 2017), especially for developing countries.

\section{Discussion}

\section{$\underline{4.1 \text { Field-based and/or remotely-sensed data? }}$}

For both methods, there are tradeoffs in terms of coverage, accuracy and cost effectiveness (Fig. 1), depending on the type of data needed to address the research objectives. Since remote-sensing methods only allow assessments of trees visible from the sky (i.e. canopy), a lot of information on both tree species diversity and forest structure is lost. In addition, technological constraints and environmental conditions, such as cloud cover, sun angle and topographic shadow, might also limit their use (Song et al. 2015). For that reason, the most accurate ways to collect biogeographical data on species diversity and forest structure still remain based on intensive field measurements. However, a strong limitation of field-based data is that their collection is very labour-intensive, and therefore very expensive to collect over large geographic areas (Segura and Kanninen 2005; Seidel et al. 2011; Wang et al. 2011). Assessments of tree species and forest structure on regional scales, such those used when studying forest fragmentation, are thus usually interpolated from relatively small field plots which can provide accurate estimates of species richness and forest structure at local scales. Nevertheless, because forest structure and tree species composition are spatially and temporally variable, interpolating data from a small number of plots to estimate species richness and forest structure for large areas is subject to high degree of uncertainty (Clark and Clark 2000; Palmer et al. 2002; Saatchi et al. 2011). 


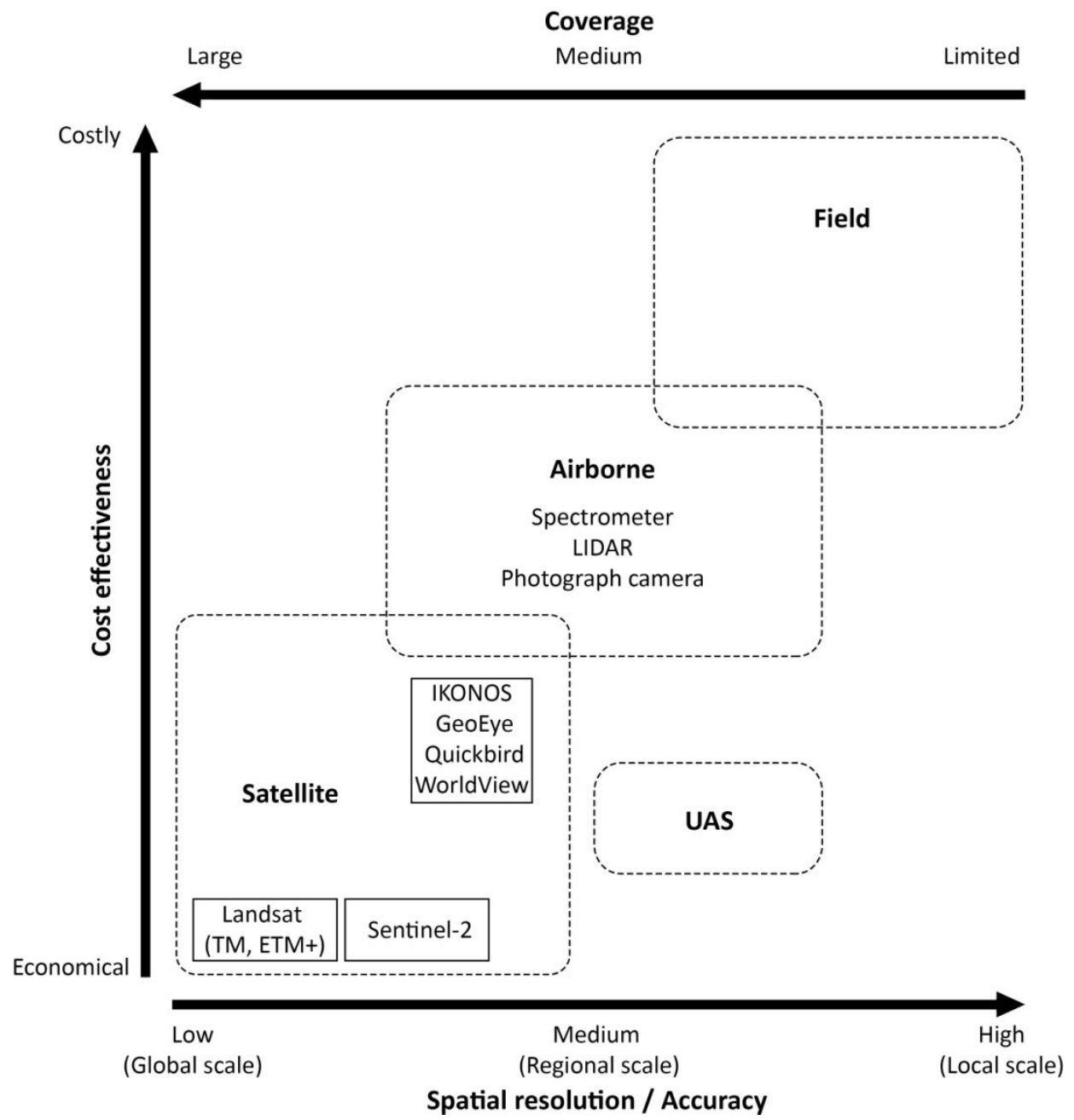

Fig. 1 Spatial resolution and cost effectiveness of field-based and remotely-sensed methods for monitoring of tree species diversity and forests structure. UAS = unmanned aerial systems.

In contrast, remotely-sensed methods can overcome the limits of field-based methods by providing measurements of forests on larger geographic scales. While lacking the accuracy of most field-based observations, remote-sensing methods allow not only lower measurement costs and less time consumed, but also access to spatially-continuous data collection over large portions of the Earth's surface (Palmer et al. 2002; Asner and Martin 2009), including unreachable forests located in remote locations or areas where conditions are dangerous. Moreover, considering that many important natural and human-induced forest disturbances occur at fine spatial scales, such as tree falls and selective logging, remote-sensing has immense potential to improve our understanding of the magnitude of biomass changes at multiple scales (Houghton 2005). Thus, while field measurement methods will remain insufficient to regularly sample large or poorly-accessible areas, especially in the tropics, monitoring methods combining field and remotely-sensed data could provide cost-effective answers to forest monitoring challenges (Asner et al. 2010). 
Based on this analysis, we also suggest these two approaches, ground-based and remote-sensing, should be complementary when applied to studies of fragmented forests. This conclusion also meets the recommendations from a review by Bustamante et al. (2016) that focused on the assessment of effects of tropical forest degradation on carbon stocks and biodiversity. Moreover, while unsupervised species classification using remote-sensing is able to predict the diversity of tree species, only ground-based inventories can provide accurate information about species composition. However, while we recognize the value of field-based inventories, a tradeoff must be made between the amount of information collected and its quality. When studying fragmented forests, it is important to assess as many forest remnants as possible in order to evaluate conservation values at the regional scale or even wider. A combination of remote-sensing and ground plots could thus provide regional scale monitoring of forest fragments and facilitate good choices in the management of those fragments. Despite their lower accuracy, remotely-sensed data could be used to map both tree species diversity and forest structure over landscape scales in order to identify priority areas for conservation. Once these priority areas have been identified, field-based measurements could be used within them to provide relatively accurate information on forest diversity and structure at a local scale and allow validation of remotely-sensed data.

To achieve this, small plots of 0.1-0.2 ha, such as the $20 \times 50 \mathrm{~m}$ plots proposed by Arellano et al. (2016), seem well suited for a fragmented landscape with small and irregularly shaped forests, as they could fit in most of the forest remnants. Although the minimum diameter measurement of $2.5 \mathrm{~cm}$ used in this method would necessarily provide better results, we suggest that a minimum diameter of $10 \mathrm{~cm}$ seems more suited for time- and costeffective assessments. Thus, for a 0.1 -ha plot it would be only necessary to measure trees $\geq 10 \mathrm{~cm}$ DBH within $10 \mathrm{~m}$ of a central $50 \mathrm{~m}$ transect line, without the need for time-consuming surveys of plot corners or boundaries. Finally, we suggest adjusting the number of plots per forest remnant as a function of the remnant size: the bigger the remnant, the more plots will be necessary for accurate assessments. Doing so approximates the method suggested by Baraloto et al. (2012), except it uses larger $20 \times 50 \mathrm{~m}$ transects and allows practical application to fragmented tropical forests even when remnants are relatively small. However, further research needs to be done to validate this approach. Optimal plot size, as well as the number of plots and area sampled, will depend on the forest being studied, study objectives, and resources available.

Considering the use of remote-sensing data, along with the $10 \mathrm{~cm} \mathrm{DBH}$ cut-off in the field-based method, we concede that this approach only focuses on canopy trees and does not account for the understory diversity (i.e. tree species that are not likely to grow into larger size classes). However, given the role played by canopies in mediating interactions among biota (Janzen 1970) and providing an environment for other flora and fauna 
(Connell 1978; Orians et al. 2012), canopy-tree diversity is usually seen as a good proxy of general biodiversity (Gentry 1988).

\subsection{Remotely-sensed techniques: a matter of tradeoff?}

Having also decided to use remote-sensing approaches in assessing fragmented tropical forests, one fundamental question remains: which approach should be chosen? Again, all approaches have pros and cons and the most appropriate largely depends on (1) the quantity of resources available and (2) the type of data needed to address the research objectives. The remote-sensing methods reviewed earlier are compared in Table 4 for their specific applicability to fragmented forest studies. The final chosen technique might be different from one study to another since the decision has to be based on the tradeoff between "data quality vs cost effectiveness".

Table 4 : Summary of remote-sensing techniques that could be used for assessment both of species diversity and forest structure in fragmented tropical forests. The technique presenting a good tradeoff between data quality and cost-effectiveness is presented in bold. UAS = unmanned aerial systems.

\begin{tabular}{lcccccc}
\hline Method & $\begin{array}{c}\text { Spatial } \\
\text { resolution }\end{array}$ & $\begin{array}{c}\text { Spectral } \\
\text { resolution }\end{array}$ & $\begin{array}{c}\text { Cost } \\
\text { effectiveness }\end{array}$ & $\begin{array}{c}\text { Labor requirements } \\
\text { over regional scale }\end{array}$ & $\begin{array}{c}\text { Coverage } \\
\text { Accuracy }\end{array}$ \\
\hline \hline Landsat (TM, ETM+) & Medium & Medium & Free & Less labour & Very large & Low \\
Sentinel-2 & Medium & Medium & Free & Less labour & Very large & Medium \\
IKONOS/GeoEye/Quickbird & High & Low & Medium cost & Less labour & Very large Medium/High \\
WorldView & High & Medium & Medium cost & Less labour & Very large & High \\
Airborne spectrometer/LiDAR & Very high & Very high & Costly & Laborious & Limited & Very high \\
UAS & Very high & Very low & Economical & Very laborious & Limited & Very high \\
\hline
\end{tabular}

An important issue in remote-sensing studies of tree species diversity and forest structure is the scale, as results are dependent on the pixel resolution (Rocchini et al. 2015). As mentioned earlier, the $30 \mathrm{~m}$ resolution of multispectral data from Landsat-TM/ETM+ satellite imagery is regarded as not good enough for assessments of species diversity and forest structure at landscape scales. Even if Landsat imagery has a higher spectral resolution than QuickBird or IKONOS sensors, the addition of redundant data can increase noise without adding valuable information, by including spectral information not related to habitat heterogeneity as noise in statistical models (Bajwa et al. 2004). On the other hand, Roth et al. (2015) recently suggested that using coarse spatial resolution (> $20 \mathrm{~m}$ ) could increase accuracy across ecosystems. However, this conclusion was based on temperate ecosystems and authors acknowledged that this result might not be true for more complex ecosystems such as tropical forests, especially when they are fragmented. 
Roth et al. (2015) discussed the important role played by patch characteristics (i.e. both size and shape) in classification success. Although the term "patch" in this study was related to a patch of the same species (or class of species) within the habitat, this discussion might be transposed to forest patches in fragmented forest studies. Roth et al. (2015) hypothesized that highest accuracy would be achieved when pixel resolution most closely approximates a species patch size and that, at coarse resolution, species occurring only in small patches cannot be mapped. This is a problem in tropical forests where almost every tree crown within a single hectare might belong to a different species; thus species patches are very small, which requires high spatial resolution. Coarse resolution is also not able to represent the edges of irregularly shaped patches as clearly as high-resolution imagery (Karl and Maurer 2010; Roth et al. 2015), the proportion of edges being much higher than in equivalent round patches. This is a crucial limitation considering that most global forest fragments present irregular shapes. These limitations also apply to spaceborne LIDAR systems, such as GLAS, or the upcoming GEDI sensor (Stavros et al. 2017). Although aimed at making height, canopy and above ground biomass metrics freely accessible, their large footprint (70 $\mathrm{m}$ for GLAS and $25 \mathrm{~m}$ for GEDI) make them very likely unsuited for assessment of forest structure in fragmented tropical forests. Thus, higher resolution is necessary to avoid too many pixels encompassing mixed species patches or habitats.

Satellite imagery such as Landsat-TM/ETM+ and GEDI sensor might still be useful for studies at continental scales (e.g. Taubert et al. 2018) where medium resolution is not as important since the region of investigation is very large. Ultimately, for studies with very limited funding, although relatively coarser in terms of quality, data accessible for free might be the only possible option. In such conditions, we recommend the use of Sentinel-2 data over Landsat imagery, as it offers a slightly higher spatial and spectral resolution. Sentinel-2a (launched 2015) and Sentinel-2b (launched 2017) have a five-day repeat equatorial overpass and offer a 10 and $20 \mathrm{~m}$ spatial resolution for eleven multispectral bands (the $60 \mathrm{~m}$ resolution of two other bands being too low). This imagery should be able to provide rough estimates of tree diversity and forest structure in fragmented forests, although further research needs to be done to validate the use of this method.

Otherwise, high-resolution imagery is needed for more accurate studies at regional scales and could be achieved using either spaceborne or airborne sensors. A problem inherent with the use of satellite-based observations in the tropics, especially in mountain areas, is the common presence of persistent cloud cover that may severely limit their use (Ticehurst et al. 2004). A solution can be the use of airborne platforms since measurements can be planned around local cloud cover dynamics. In addition, airborne techniques offer far more spectral information 
than current satellite-based approaches, which is very useful for species identification and characterization of forest structure. However, the coverage of these airborne techniques is usually limited by their small swaths and their very high cost per hectare covered, due to the use of either planes or helicopters. This review aims to make recommendations for rapid and cost-effective assessments in fragmented tropical forests. Since most of this topic concerns developing countries, it is likely that these types of airborne sensors may be prohibitively costly and inaccessible for researchers, except when funded by developed countries.

For fragmented tropical forests, we suggest as a good compromise the use of high-resolution imagery from satellite sensors such as IKONOS, Quickbird or Worldview. They offer the advantage of allowing reasonably accurate estimates of both canopy diversity and forest structure using a single sensor (i.e. no need for additional data such as LIDAR) while being immediately available for medium costs over very large areas. Moreover, considering the decrease in cost for such images observed over the last decades, it is to be expected that they will become even cheaper in the future, making them affordable even for researchers with limited funding. In contrast with airborne systems, a limitation to diversity estimation using such imagery might be the absence of hyperspectral data. However, while hyperspectral data are needed for species identification, we believe that the multispectral data provided by these sensors might be enough for an approximate prediction of species diversity. Worldview particularly is able to provide images with up to eight spectral bands at a resolution of $2 \mathrm{~m}$, which is probably enough to provide relatively good estimates of both species diversity and stand structure.

Concerning the problem related to cloud cover using satellite imagery, the combination of several images should be able to produce a cloud-free image in most cases. Ultimately, for areas with consistent cloud cover all year long (as reported by Asner (2001) in some parts of Brazilian Amazonia), a cost-effective alternative might be the use of UAS. Drones can provide high-resolution imagery, as well as hyper spectral images and LiDAR data. In the literature, recent studies using UAS have been able to record high-resolution images of areas from less than 100 ha (Ota et al. 2017) up to about 2500 ha (Michez et al. 2016). Theoretically, although considerable time might be necessary for image acquisition and georeferencing, this approach can be used over much larger areas. However, this promising approach still needs to be developed and described in further studies, especially in more complex ecosystems such as tropical forests. Thus, for now, this recommendation only applies when the use of high-resolution imagery from satellite sensors is impossible.

\section{Conclusion}


Assessment of both tree species diversity and forest structure is needed at local and regional levels to understand the present status of fragmented tropical forests and to develop effective management strategies for their conservation. In this paper, we have reviewed a range of candidate sampling techniques and measurement methods with potential to achieve these objectives. For most studies, the availability of time, money and manpower is the major constraint. Several methods using either ground-based or remotely-sensed techniques were discussed in this review in order to identify candidate methods for rapid and cost-effective assessments of tree species diversity and forest structure in fragmented forests. To summarize, the methods should satisfy the objectives of the study and also characterize the inherent diversity status of a region of investigation at acceptable costs. We suggest combining the use of both field-based and remotely-sensed methods to achieve that goal as these methods can be complementary. Remote-sensing data should be used to predict and map the tree species diversity and stand structure at regional scales, while field-inventories provide accurate information at local scales and allow validation of remotely-sensed data. For field-based inventories, we recommend the use of small (e.g. $20 \times 50 \mathrm{~m}$ ) plots with a $10 \mathrm{~cm} \mathrm{DBH}$ minimum measurement. If funding is not a problem, airborne imagery seems the best in terms of quality of information (i.e. hyperspectral and hyperspatial imagery, LiDAR). A more cost-effective alternative providing reasonably accurate estimates would be the use of high-resolution satellite imagery such as Worldview. Ultimately, for studies where data accessible for free is the only possible option, we recommend the use of Sentinel-2, although it is relatively coarser in terms of quality. In any case, further research needs to be done to validate these approaches in fragmented tropical forests.

\section{Acknowledgements}

We are grateful to the Faculty of Agribusiness and Commerce, Lincoln University, for providing research seed funding to support EG while working on this paper. We also record our appreciation to Justin Morgenroth and two anonymous reviewers for giving useful comments on an earlier version of this paper.

\section{References}

Alder D, Synnott TJ (1992) Permanent sample plot techniques for mixed tropical forest. Oxford Forestry Institute, University of Oxford.

Alroy J (2017) Effects of habitat disturbance on tropical forest biodiversity. Proceedings of the National Academy of Sciences, 114(23):6056-6061. https://doi.org/10.1073/pnas.1611855114 
Anderson MJ, Crist TO, Chase JM et al. (2011) Navigating the multiple meanings of beta diversity: a roadmap for the practicing ecologist. Ecology Letters, 14:19-28.

Arellano G, Cala V, Fuentes A, Cayola L, Jørgensen PM, Macía MJ (2016) A standard protocol for woody plant inventories and soil characterisation using temporary 0.1-ha plots in tropical forests. Journal of Tropical Forest Science, 28:508-516. http://www.jstor.org/stable/43956817

Arekhi M, Yılmaz OY, Yılmaz H, Akyüz YF (2017) Can tree species diversity be assessed with Landsat data in a temperate forest? Environmental Monitoring and Assessment, 189:586. https://doi.org/10.1007/s10661-0176295-6

Asner GP (2001) Cloud cover in Landsat observations of the Brazilian Amazon. International Journal of Remote Sensing, 22(18):3855-3862. https://doi.org/10.1080/01431160010006926

Asner GP (2015) Organismic remote sensing for tropical forest ecology and conservation. Annals of the Missouri Botanical Garden, 100:127-140. https://doi.org/10.3417/2012016

Asner GP, Anderson CB, Martin RE., Knapp DE, Tupayachi R, Sinca F, Malhi Y (2014) Landscape-scale changes in forest structure and functional traits along an Andes-to-Amazon elevation gradient. Biogeosciences, 11:843-856. https://doi.org/10.5194/bg-11-843-2014

Asner GP, Knapp DE, Kennedy-Bowdoin T, Jones MO, Martin RE, Boardman JW, Field CB (2007) Carnegie airborne observatory: in-flight fusion of hyperspectral imaging and waveform light detection and ranging for three-dimensional studies of ecosystems. Journal of Applied Remote Sensing, 1. https://doi.org/10.1117/1.2794018

Asner GP, Knapp DE, Kennedy-Bowdoin T, Jones MO, Martin RE, Boardman J, Hughes RF (2008) Invasive species detection in Hawaiian rainforests using airborne imaging spectroscopy and LiDAR. Remote Sensing of Environment, 112:1942-1955. https://doi.org/10.1016/j.rse.2007.11.016

Asner GP, Martin RE (2009) Airborne spectranomics: mapping canopy chemical and taxonomic diversity in tropical forests. Frontiers in Ecology and the Environment, 7:269-276. https://doi.org/10.1890/070152

Asner GP, Martin RE (2011) Canopy phylogenetic, chemical and spectral assembly in a lowland Amazonian forest. New Phytologist, 189:999-1012. https://doi.org/10.1111/j.1469-8137.2010.03549.x 
Asner GP, Martin RE, Ford AJ, Metcalfe DJ, Liddell MJ (2009) Leaf chemical and spectral diversity in Australian tropical forests. Ecological Applications, 19:236-253. https://doi.org/10.1890/08-0023.1

Asner GP, Martin RE, Suhaili AB (2012a) Sources of canopy chemical and spectral diversity in lowland Bornean forest. Ecosystems, 15:504-517. https://doi.org/10.1007/s10021-012-9526-2

Asner GP, Mascaro J, Muller-Landau HC, Vieilledent G, Vaudry R, Rasamoelina M, Hall J, Van Breugel M (2012b) A universal airborne LiDAR approach for tropical forest carbon mapping. Oecologia, 168:1147-1160. https://doi.org/10.1007/s00442-011-2165-z

Asner GP, Palace M, Keller M, Pereira Jr R, Silva JN, Zweede JC (2002) Estimating canopy structure in an Amazon forest from laser range finder and IKONOS satellite observations. Biotropica, 34:483-492. https://doi.org/10.1646/0006-3606(2002)034[0483:ECSIAA]2.0.CO;2

Asner GP, Powell GV, Mascaro J, Knapp DE, Clark JK, Jacobson J, Kennedy-Bowdoin T, Balaji A, PaezAcosta G, Victoria E, Secada L, Valqui M, Hughes RF (2010) High-resolution forest carbon stocks and emissions in the Amazon. Proceedings of the National Academy of Sciences, 107:16738-16742. https://doi.org/10.1073/pnas.1004875107

Avena GC, Ricotta C, Volpe F (1999) The influence of principal component analysis on the spatial structure of a multispectral dataset. International Journal of Remote Sensing, 20:3367-3376. https://doi.org/10.1080/014311699211381

Baccini AGSJ, Goetz SJ, Walker WS, Laporte NT, Sun M, Sulla-Menashe D, Hackler J, Beck PSA, Dubayah R, Friedl MA, Samanta S, Houghton RA (2012) Estimated carbon dioxide emissions from tropical deforestation improved by carbon-density maps. Nature Climate Change, 2:182-185. https://doi.org/10.1038/nclimate1354

Baldeck CA, Asner GP (2013) Estimating vegetation beta diversity from airborne imaging spectroscopy and unsupervised clustering. Remote Sensing, 5:2057-2071. https://doi.org/10.3390/rs5052057

Baldeck CA, Asner GP, Martin RE, Anderson CB, Knapp DE, Kellner JR, Wright SJ (2015) Operational tree species mapping in a diverse tropical forest with airborne imaging spectroscopy. PLoS One, 10:e0118403. https://doi.org/10.1371/journal.pone.0118403

Bajwa SG, Bajcsy P, Groves P, Tian LF (2004) Hyperspectral image data mining for band selection in agricultural applications. Transactions of the ASAE, 47:895-907. https://doi.org/10.13031/2013.16087 
Baraloto C, Molto Q, Rabaud S, Hérault B, Valencia R, Blanc L, Fine PV, Thompson J (2012) Rapid simultaneous estimation of aboveground biomass and tree diversity across Neotropical forests: a comparison of field inventory methods. Biotropica, 45:288-298. https://doi.org/10.1111/btp.12006

Baraloto C, Rabaud S, Molto Q, Blanc L, Fortunel C, Hérault B, Dávila N, Mesones I, Rios M, Valderrama E, Fine PV (2011) Disentangling stand and environmental correlates of aboveground biomass in Amazonian forests. Global Change Biology, 17:2677-2688. https://doi.org/10.1111/j.1365-2486.2011.02432.x

Barbier N, Couteron P, Gastelly-Etchegorry JP, Proisy C (2012) Linking canopy images to forest structural parameters: potential of a modeling framework. Annals of Forest Science, 69:305-311. https://doi.org/10.1007/s13595-011-0116-9

Barbosa JM, Melendez-Pastor I, Navarro-Pedreño J, Bitencourt MD (2014) Remotely sensed biomass over steep slopes: An evaluation among successional stands of the Atlantic Forest, Brazil. ISPRS Journal of Photogrammetry and Remote Sensing, 88:91-100. https://doi.org/10.1016/j.isprsjprs.2013.11.019

Bastin JF, Barbier N, Couteron P, Adams B, Shapiro A, Bogaert J, De Cannière C (2014) Aboveground biomass mapping of African forest mosaics using canopy texture analysis: toward a regional approach. Ecological Applications, 24:1984-2001. https://doi.org/10.1890/13-1574.1

Baynes J, Herbohn J, Chazdon RL, Nguyen H, Firn J, Gregorio N, Lamb D (2016) Effects of fragmentation and landscape variation on tree diversity in post-logging regrowth forests of the Southern Philippines. Biodiversity and Conservation, 25:923-941. https://doi.org/10.1007/s10531-016-1098-6

Bergen KM, Goetz SJ, Dubayah RO, Henebry GM, Hunsaker CT, Imhoff ML, Nelson RF, Parker GG, Radeloff VC (2009) Remote sensing of vegetation 3-D structure for biodiversity and habitat: review and implications for lidar and radar spaceborne missions. Journal of Geophysical Research: Biogeosciences, 114. https://doi.org/10.1029/2008JG000883

Blanchard E, Birnbaum P, Proisy C, Ibanez T, Vandrot H, Chambrey C, Hequet V, Couteron P (2015) Prédire la structure des forêts tropicales humides calédoniennes: analyse texturale de la canopée sur des images Pléiades. Revue Française de Photogrammétrie et de Télédétection, 209:141-147. http://hal.ird.fr/ird-01137604/ 
Blaschke T, Hay GJ, Kelly M, Lang S, Hofmann P, Addink E, Queiroz Feitosa R, van der Meer F, van der Werff H, van Coillie F, Tiede D (2014) Geographic object-based image analysis-towards a new paradigm. ISPRS Journal of Photogrammetry and Remote Sensing, 87:180-191. https://doi.org/10.1016/j.isprsjprs.2013.09.014

Boyle BL (1996) Changes on altitudinal and latitudinal gradients in neotropical montane forests, pp 275. Washington University, St Louis, Missouri.

Bustamante MM, Roitman I, Aide TM, Alencar A, Anderson LO, Aragão L et al. (2016) Toward an integrated monitoring framework to assess the effects of tropical forest degradation and recovery on carbon stocks and biodiversity. Global Change Biology, 22(1):92-109. https://doi.org/10.1111/gcb.13087

Carlson KM, Asner GP, Hughes RF, Ostertag R, Martin RE (2007) Hyperspectral remote sensing of canopy biodiversity in Hawaiian lowland rainforests. Ecosystems, 10:536-549. https://doi.org/10.1007/s10021-0079041-z

Campbell P, Comiskey J, Alonso A, Dallmeier F, Nuñez P, Beltran H, Baldeon S, Nauray W, de la Colina R, Udvardy S (2002) Modified Whittaker plots as an assessment and monitoring tool for vegetation in a lowland tropical rainforest. Environmental Monitoring and Assessment, 76:19-41. https://doi.org/10.1023/A:1015264720284

Chambers JQ, Asner GP, Morton DC, Anderson LO, Saatchi SS, Espírito-Santo FD, Palace M, Souza Jr C (2007) Regional ecosystem structure and function: ecological insights from remote sensing of tropical forests. Trends in Ecology and Evolution, 22:414-423. https://doi.org/10.1016/j.tree.2007.05.001

Cho MA, Malahlela O, Ramoelo A (2015) Assessing the utility WorldView-2 imagery for tree species mapping in South African subtropical humid forest and the conservation implications: Dukuduku forest patch as case study. International Journal of Applied Earth Observation and Geoinformation, 38:349-357. https://doi.org/10.1016/j.jag.2015.01.015

Cho MA, Mathieu R, Asner GP, Naidoo L, van Aardt J, Ramoelo A, Debba P, Wessels K, Main R, Smit LPJ, Erasmus B (2012) Mapping tree species composition in South African savannas using an integrated airborne spectral and LiDAR system. Remote Sensing of Environment, 125:214-226. https://doi.org/10.1016/j.rse.2012.07.010 
Clark DA, Brown S, Kicklighter DW, Chambers JQ, Thomlinson JR, Ni J (2001) Measuring net primary production in forests: concepts and field methods. Ecological Applications, 11:356-370. https://doi.org/10.1890/1051-0761(2001)011[0356:MNPPIF]2.0.CO;2

Clark DB, Clark DA (2000) Landscape-scale variation in forest structure and biomass in a tropical rain forest. Forest Ecology and Management, 137:185-198. https://doi.org/10.1016/S0378-1127(99)00327-8

Clark ML, Clark DB, Roberts DA (2004) Small-footprint lidar estimation of sub-canopy elevation and tree height in a tropical rain forest landscape. Remote Sensing of Environment, 91:68-89. https://doi.org/10.1016/j.rse.2004.02.008

Clark ML, Roberts DA (2012) Species-level differences in hyperspectral metrics among tropical rainforest trees as determined by a tree-based classifier. Remote Sensing, 4:1820-1855. https://doi.org/10.3390/rs4061820

Clark ML, Roberts DA, Clark DB (2005) Hyperspectral discrimination of tropical rain forest tree species at leaf to crown scales. Remote Sensing of Environment, 96:375-398. https://doi.org/10.1016/j.rse.2005.03.009

Clark ML, Roberts DA, Ewel JJ, Clark DB (2011) Estimation of tropical rain forest aboveground biomass with small-footprint lidar and hyperspectral sensors. Remote Sensing of Environment, 115:2931-2942. https://doi.org/10.1016/j.rse.2010.08.029

Cochrane MA (2000) Using vegetation reflectance variability for species level classification of hyperspectral data. International Journal of Remote Sensing, 21:2075-2087. https://doi.org/10.1080/01431160050021303

Colgan MS, Baldeck CA, Féret JB, Asner GP (2012) Mapping savanna tree species at ecosystem scales using support vector machine classification and BRDF correction on airborne hyperspectral and LiDAR data. Remote Sensing, 4:3462-3480. https://doi.org/10.3390/rs4113462

Condit R (1995) Research in large, long-term tropical forest plots. Trends in Ecology and Evolution, 10:18-22. https://doi.org/10.1016/S0169-5347(00)88955-7

Condit R, Pitman N, Leigh EG, Chave J, Terborgh J, Foster RB, Nuñez P, Aguilar S, Valencia, R, Villa G, Muller-Landau HC, Losos E, Hubbell SP (2002) Beta-diversity in tropical forest trees. Science, 295:666-669. https://doi.org/10.1126/science.1066854 
Connell JH (1978) Diversity in tropical rain forests and coral reefs. Science, 199:1302-1310. https://doi.org/10.1126/science.199.4335.1302

Corbane C, Lang S, Pipkins K, Alleaume S, Deshayes M, Millán VEG, Strasser T, Borre JV, Toon S, Michael F (2015) Remote sensing for mapping natural habitats and their conservation status-New opportunities and challenges. International Journal of Applied Earth Observation and Geoinformation, 37:7-16. https://doi.org/10.1016/j.jag.2014.11.005

Corona P, Fattorini L (2008) Area-based lidar-assisted estimation of forest standing volume. Canadian Journal of Forest Research, 38:2911-2916. https://doi.org/10.1139/X08-122

Couteron P, Pelissier R, Nicolini EA, Paget D (2005) Predicting tropical forest stand structure parameters from Fourier transform of very high-resolution remotely sensed canopy images. Journal of Applied Ecology, 42:11211128. https://doi.org/10.1111/j.1365-2664.2005.01097.x

Curran PJ (1989) Remote sensing of foliar chemistry. Remote Sensing of Environment, 30:271-278. https://doi.org/10.1016/0034-4257(89)90069-2

Dalponte M, Bruzzone L, Gianelle D (2008) Fusion of hyperspectral and LIDAR remote sensing data for classification of complex forest areas. IEEE Transactions on Geoscience and Remote Sensing, 46:1416-1427. https://doi.org/10.1109/TGRS.2008.916480

Dinuls R, Erins G, Lorencs A, Mednieks I, Sinica-Sinavskis J (2012) Tree species identification in mixed Baltic forest using LiDAR and multispectral data. IEEE Journal of Selected Topics in Applied Earth Observations and Remote Sensing, 5:594-603.

Drake JB, Dubayah RO, Clark DB, Knox RG, Blair JB, Hofton MA, Chazdon R, Weishampel JF, Prince, SD (2002) Estimation of tropical forest structural characteristics using large-footprint lidar. Remote Sensing of Environment, 79:305-319. https://doi.org/10.1016/S0034-4257(01)00281-4

Dunford R, Michel K, Gagnage M, Piégay H, Trémelo ML (2009) Potential and constraints of Unmanned Aerial Vehicle technology for the characterization of Mediterranean riparian forest. International Journal of Remote Sensing, 30:4915-4935. https://doi.org/10.1080/01431160903023025

Evans TD, Viengkham OV (2001) Inventory time-cost and statistical power: a case study of a Lao rattan. Forest Ecology and Management, 150(3):313-322. https://doi.org/10.1016/S0378-1127(00)00589-2 
Everitt JH, Yang C, Deloach CJ (2005) Remote sensing of giant reed with QuickBird satellite imagery. Journal of Aquatic Plant Management, 43:81-85.

Ewers RM, Didham RK (2006) Confounding factors in the detection of species responses to habitat fragmentation. Biological Reviews, 81:117-142. https://doi.org/10.1017/S1464793105006949

Fahrig L (2003) Effects of habitat fragmentation on biodiversity. Annual Review of Ecology, Evolution and Systematics, 34:487-515. https://doi.org/10.1146/annurev.ecolsys.34.011802.132419

FAO (1981) Manual of forest inventory with special reference to mixed tropical forests. FAO, Rome, Italy.

Fassnacht FE, Latifi H, Stereńczak K, Modzelewska A, Lefsky M, Waser LT, Straub C, Ghosh A (2016) Review of studies on tree species classification from remotely sensed data. Remote Sensing of Environment, 186:64-87. https://doi.org/10.1016/j.rse.2016.08.013

Feeley KJ, Silman MR (2011) The data void in modeling current and future distributions of tropical species. Global Change Biology, 17:626-630. https://doi.org/10.1111/j.1365-2486.2010.02239.x

Feldpausch TR, Banin L, Phillips OL, Baker TR, Lewis SL. Quesada CA, et al. (2010) Height-diameter allometry of tropical forest trees. Biogeosciences Discussions, 7:7727-7793. http://dx.doi.org/10.5194/bgd-7$7727-2010$

Féret JB, Asner GP (2012) Semi-supervised methods to identify individual crowns of lowland tropical canopy species using imaging spectroscopy and LiDAR. Remote Sensing, 4:2457-2476. https://doi.org/10.3390/rs4082457

Féret JB, Asner GP (2014) Mapping tropical forest canopy diversity using high-fidelity imaging spectroscopy. Ecological Applications, 24:1289-1296. https://doi.org/10.1890/13-1824.1

Foody GM, Boyd DS, Cutler ME (2003) Predictive relations of tropical forest biomass from Landsat TM data and their transferability between regions. Remote Sensing of Environment, 85:463-474. https://doi.org/10.1016/S0034-4257(03)00039-7

Foster RB, Hernandez NC, Kakudidi EK, Burnham RJ (1998) Rapid assessment of tropical plant communities using variable transects: an informal and practical guide. Field Museum of Chicago, Chicago, Illinois. 
Franklin SE, Ahmed OS, Williams G (2017) Northern Conifer Forest Species Classification Using Multispectral Data Acquired from an Unmanned Aerial Vehicle. Photogrammetric Engineering and Remote Sensing, 83:501507. https://doi.org/10.14358/PERS.83.7.501

Gaston KJ (2000) Global patterns in biodiversity. Nature, 405:220-227. https://doi.org/10.1038/35012228

Gentry AH (1988) Changes in plant community diversity and floristic composition on environmental and geographical gradients. Annals of the Missouri Botanical Garden, 75:1-34. http://www.jstor.org/stable/2399464

Getzin S, Wiegand K, Schöning I (2012) Assessing biodiversity in forests using very high-resolution images and unmanned aerial vehicles. Methods in Ecology and Evolution, 3:397-404. https://doi.org/10.1111/j.2041210X.2011.00158.X

Ghosh A, Fassnacht FE, Joshi PK, Koch B (2014) A framework for mapping tree species combining hyperspectral and LiDAR data: Role of selected classifiers and sensor across three spatial scales. International Journal of Applied Earth Observation and Geoinformation, 26:49-63. https://doi.org/10.1016/j.jag.2013.05.017

Gillespie TW, Foody GM, Rocchini D, Giorgi AP, Saatchi S (2008) Measuring and modelling biodiversity from space. Progress in Physical Geography, 32:203-221. https://doi.org/10.1177/0309133308093606

Gillespie TW, Saatchi S, Pau S, Bohlman S, Giorgi AP, Lewis S (2009) Towards quantifying tropical tree species richness in tropical forests. International Journal of Remote Sensing, 30:1629-1634. https://doi.org/10.1080/01431160802524552

Gini R, Passoni D, Pinto L, Sona G (2014) Use of Unmanned Aerial Systems for multispectral survey and tree classification: a test in a park area of northern Italy. European Journal of Remote Sensing, 47:251-269. https://doi.org/10.5721/EuJRS20144716

Gougeon FA (1995) A crown-following approach to the automatic delineation of individual tree crowns in high spatial resolution aerial images. Canadian Journal of Remote Sensing, 21:274-284. https://doi.org/10.1080/07038992.1995.10874622

Groombridge B, Jenkins M (2000) Global biodiversity: Earth's living resources in the 21st century. Cambridge, UK: World Conservation Press. 
Grussu G, Testolin R, Saulei S, Farcomeni A, Yosi CK, De Sanctis M, Attorre F (2015) Optimum plot and sample sizes for carbon stock and biodiversity estimation in the lowland tropical forests of Papua New Guinea. Forestry, 89(2):150-158. https://doi.org/10.1093/forestry/cpv047

Haddad NM, Brudvig LA, Clobert J, Davies KF, Gonzalez A, Holt RD (2015) Habitat fragmentation and its lasting impact on Earth's ecosystems. Science Advances, 1:e1500052. https://doi.org/10.1126/sciadv.1500052

Hakkenberg CR, Zhu K, Peet RK, Song C (2018) Mapping multi-scale vascular plant richness in a forest landscape with integrated LiDAR and hyperspectral remote-sensing. Ecology, 99:474-487. https://doi.org/10.1002/ecy.2109

Hamer KC, Hill JK, Lace LA, Langan AM (1997) Ecological and biogeographical effects of forest disturbance on tropical butterflies of Sumba, Indonesia. Journal of Biogeography, 24:67-75. https://doi.org/10.1111/j.13652699.1997.tb00051.x

Harper KA, Macdonald SE, Burton PJ, Chen J, Brosofske KD, Saunders SC, Euskirchen ES, Roberts D, Jaiteh MS, Essen P-A (2005) Edge Influence on Forest Structure and Composition in Fragmented Landscapes. Conservation Biology, 19(3):768-782. https://doi.org/10.1111/j.1523-1739.2005.00045.x

He KS, Rocchini D, Neteler M, Nagendra H (2011) Benefits of hyperspectral remote sensing for tracking plant invasions. Diversity and Distributions, 17:381-392. https://doi.org/10.1111/j.1472-4642.2011.00761.x

Heinken T, Weber E (2013) Consequences of habitat fragmentation for plant species: Do we know enough? Perspectives in Plant Ecology, Evolution and Systematics, 15:205-216. https://doi.org/10.1016/j.ppees.2013.05.003

Helm A, Hanski I, Partel M (2006) Slow response of plant species richness to habitat loss and fragmentation. Ecology Letters, 9:72-77. https://doi.org/10.1111/j.1461-0248.2005.00841.x

Henry M, Réjou-Méchain M, Jara MC, Wayson C, Piotto D, Westfall J, et al. (2015) An overview of existing and promising technologies for national forest monitoring. Annals of Forest Science, 72:779-788. https://doi.org/10.1007/s13595-015-0463-z 
Hernández-Stefanoni JL, Dupuy JM (2007) Mapping species density of trees, shrubs and vines in a tropical forest, using field measurements, satellite multiespectral imagery and spatial interpolation. Biodiversity and Conservation, 16:3817-3833. https://doi.org/10.1007/s10531-007-9182-6

Hernández-Stefanoni JL, Gallardo-Cruz JA, Meave JA, Dupuy JM (2011) Combining geostatistical models and remotely sensed data to improve tropical tree richness mapping. Ecological Indicators, 11:1046-1056. https://doi.org/10.1016/j.ecolind.2010.11.003

Hernández-Stefanoni JL, Gallardo-Cruz JA, Meave JA, Rocchini D, Bello-Pineda J, López-Martínez JO (2012) Modeling $\alpha$-and $\beta$-diversity in a tropical forest from remotely sensed and spatial data. International Journal of Applied Earth Observation and Geoinformation, 19:359-368. https://doi.org/10.1016/j.jag.2012.04.002

Heurich M, Thoma F (2008) Estimation of forestry stand parameters using laser scanning data in temperate, structurally rich natural European beech (Fagus sylvatica) and Norway spruce (Picea abies) forests. Forestry, 81:645-661. https://doi.org/10.1093/forestry/cpn038

Higgins MA, Ruokolainen K (2004) Rapid tropical forest inventory: a comparison of techniques based on inventory data from western Amazonia. Conservation Biology, 18:799-811. https://doi.org/10.1111/j.15231739.2004.00235.x

Hill JL, Curran PJ (2003) Area, shape and isolation of tropical forest fragments: effects on tree species diversity and implications for conservation. Journal of biogeography, 30(9):1391-1403. https://doi.org/10.1046/j.13652699.2003.00930.x

Holmgren J, Persson Å, Söderman U (2008) Species identification of individual trees by combining high resolution LiDAR data with multi-spectral images. International Journal of Remote Sensing, 29:1537-1552. https://doi.org/10.1080/01431160701736471

Hou Z, Xu Q, Tokola T (2011) Use of ALS, Airborne CIR and ALOS AVNIR-2 data for estimating tropical forest attributes in Lao PDR. ISPRS Journal of Photogrammetry and Remote Sensing, 66:776-786. https://doi.org/10.1016/j.isprsjprs.2011.09.005

Houghton RA (1994) The worldwide extent of land-use change. Bioscience, 44:305-313. http://www.jstor.org/stable/1312380 
Houghton RA (2005) Aboveground forest biomass and the global carbon balance. Global Change Biology, 11:945-958. https://doi.org/10.1111/j.1365-2486.2005.00955.x

Hruska R, Mitchell J, Anderson M, Glenn NF (2012) Radiometric and geometric analysis of hyperspectral imagery acquired from an unmanned aerial vehicle. Remote Sensing, 4:2736-2752. https://doi.org/10.3390/rs4092736

Huggett RJ (1995) Geoecology: An Evolutionary Approach. Routledge, New York.

Hyyppä J, Hyyppä H, Leckie D, Gougeon F, Yu X, Maltamo M (2008) Review of methods of small-footprint airborne laser scanning for extracting forest inventory data in boreal forests. International Journal of Remote Sensing, 29:1339-1366. https://doi.org/10.1080/01431160701736489

Ibanez T, Hequet V, Chambrey C, Jaffré T, Birnbaum P (2017) How does forest fragmentation affect tree communities? A critical case study in the biodiversity hotspot of New Caledonia. Landscape Ecology, 32:16711687. https://doi.org/10.1007/s10980-017-0534-7

Immitzer M, Atzberger C, Koukal T (2012) Tree species classification with random forest using very high spatial resolution 8-band WorldView-2 satellite data. Remote Sensing, 4:2661-2693. https://doi.org/10.3390/rs4092661

Immitzer M, Vuolo F, Atzberger C (2016) First experience with Sentinel-2 data for crop and tree species classifications in central Europe. Remote Sensing, 8(3):166. https://doi.org/10.3390/rs8030166

Janzen DH (1970) Herbivores and the number of tree species in tropical forests. The American Naturalist, 104:501-528. https://doi.org/10.1086/282687

Jayakumar S, Kim SS, Heo J (2011) Floristic inventory and diversity assessment - a critical review. Proceedings of the International Academy of Ecology and Environmental Sciences, 1:151-168.

Jones TG, Coops NC, Sharma T (2010) Assessing the utility of airborne hyperspectral and LiDAR data for species distribution mapping in the coastal Pacific Northwest, Canada. Remote Sensing of Environment, 114:2841-2852. https://doi.org/10.1016/j.rse.2010.07.002 
Kachamba DJ, Ørka HO, Gobakken T, Eid T, Mwase W (2016) Biomass estimation using 3D data from unmanned aerial vehicle imagery in a tropical woodland. Remote Sensing, 8:968. https://doi.org/10.3390/rs8110968

Kangas A, Maltamo M (2006) Forest inventory: methodology and applications (Vol. 10). Kangas A, Maltamo M (eds). Springer Science and Business Media, Berlin.

Karl JW, Maurer BA (2010) Multivariate correlations between imagery and field measurements across scales: comparing pixel aggregation and image segmentation. Landscape Ecology, 25(4):591-605. https://doi.org/10.1007/s10980-009-9439-4

Kerr JT, Ostrovsky M (2003) From space to species: ecological applications for remote sensing. Trends in Ecology and Evolution, 18:299-305. https://doi.org/10.1016/S0169-5347(03)00071-5

Koetz B, Sun G, Morsdorf F, Ranson KJ, Kneubühler M, Itten K, Allgöwer B (2007) Fusion of imaging spectrometer and LIDAR data over combined radiative transfer models for forest canopy characterization. Remote Sensing of Environment, 106:449-459. https://doi.org/10.1016/j.rse.2006.09.013

Koh LP, Sodhi NS (2010) Conserving Southeast Asia's imperiled biodiversity: scientific, management, and policy challenges. Biodiversity and Conservation, 19:913-917. https://doi.org/10.1007/s10531-010-9818-9

Koh LP, Wich SA (2012) Dawn of drone ecology: low-cost autonomous aerial vehicles for conservation. Tropical Conservation Science, 5:121-132. https://doi.org/10.1177/194008291200500202

Koh LP, Wilcove DS (2008) Is oil palm agriculture really destroying tropical biodiversity? Conservation Letters, 1:60-64. https://doi.org/10.1111/j.1755-263X.2008.00011.x

Krauss J, Bommarco R, Guardiola M (2010) Habitat fragmentation causes immediate and time-delayed biodiversity loss at different trophic levels. Ecology Letters, 13:597-605. https://doi.org/10.1111/j.14610248.2010.01457.x

Kuenzer C, Ottinger M, Wegmann M, Guo H, Wang C, Zhang J, Dech S, Wikelski M (2014) Earth observation satellite sensors for biodiversity monitoring: potentials and bottlenecks. International Journal of Remote Sensing, 35:6599-6647. https://doi.org/10.1080/01431161.2014.964349 
Laba M, Blair B, Downs R, Monger B, Philpot W, Smith S, Sullivan P, Baveye PC (2010) Use of textural measurements to map invasive wetland plants in the Hudson River National Estuarine Research Reserve with IKONOS satellite imagery. Remote Sensing of Environment, 114:876-886. https://doi.org/10.1016/j.rse.2009.12.002

Latifi H, Fassnacht FE, Hartig F, Berger C, Hernández J, Corvalán P, Koch B (2015) Stratified aboveground forest biomass estimation by remote sensing data. International Journal of Applied Earth Observation and Geoinformation, 38:229-241. https://doi.org/10.1016/j.jag.2015.01.016

Laurance WF (2008) Theory meets reality: How habitat fragmentation research has transcended island biogeographic theory. Biological Conservation, 141:1731-1744. https://doi.org/10.1016/j.biocon.2008.05.011

Laurance WF, Bierregaard R (1997) Tropical forest remnants: ecology, management, and conservation of fragmented communities. University of Chicago, Chicago, IL, USA.

Laurin GV, Chan JCW, Chen Q, Lindsell JA, Coomes DA, Guerriero L, del Frate F, Milglietta F, Valentini R (2014) Biodiversity mapping in a tropical West African forest with airborne hyperspectral data. PloS One, 9:e97910. https://doi.org/10.1371/journal.pone.0097910

Laurin GV, Puletti N, Hawthorne W, Liesenberg V, Corona P, Papale D, Chen Q, Valentini R (2016) Discrimination of tropical forest types, dominant species, and mapping of functional guilds by hyperspectral and simulated multispectral Sentinel-2 data. Remote Sensing of Environment, 176:163-176. https://doi.org/10.1016/j.rse.2016.01.017

Lausch A, Bannehr L, Beckmann M, Boehm C, Feilhauer H, Hacker JM, Heurich M, Jung A, Klenke R, Neumann C, Pause M, Rocchini D, Schaepman ME, Schmidtlein S, Schulz K, Selsam P, Settele J, Skidmore AK, Cord AF (2016) Linking Earth Observation and taxonomic, structural and functional biodiversity: Local to ecosystem perspectives. Ecological Indicators, 70:317-339. https://doi.org/10.1016/j.ecolind.2016.06.022

Lee HS, Davies SJ, LaFrankie JV, Tan S, Yamakura T, Itoh A, Ohkubo T, Ashton PS (2002) Floristic and structural diversity of mixed dipterocarp forest in Lambir Hills National Park, Sarawak, Malaysia. Journal of Tropical Forest Science, 14:379-400. http://www.jstor.org/stable/43594474 
Lefsky MA, Cohen WB, Harding DJ, Parker GG, Acker SA, Gower ST (2002a) Lidar remote sensing of above-ground biomass in three biomes. Global Ecology and Biogeography, 11:393-399. https://doi.org/10.1046/j.1466-822x.2002.00303.x

Lefsky MA, Cohen WB, Parker WB, Harding DJ (2002b) Lidar Remote Sensing for Ecosystem Studies: Lidar, an emerging remote sensing technology that directly measures the three-dimensional distribution of plant canopies, can accurately estimate vegetation structural attributes and should be of particular interest to forest, landscape, and global ecologists. BioScience, 52:19-30. https://doi.org/10.1641/00063568(2002)052[0019:LRSFES]2.0.CO;2

Lefsky MA, Keller M, Pang Y, De Camargo PB, Hunter MO (2007) Revised method for forest canopy height estimation from Geoscience Laser Altimeter System waveforms. Journal of Applied Remote Sensing, 1:1-18. https://doi.org/10.1117/1.2795724

Leutner BF, Reineking B, Müller J, Bachmann M, Beierkuhnlein C, Dech S, Wegmann M (2012) Modelling forest $\alpha$-diversity and floristic composition - on the added value of LiDAR plus hyperspectral remote sensing. Remote Sensing, 4:2818-2845. https://doi.org/10.3390/rs4092818

Lewis SL, Edwards DP, Galbraith D (2015) Increasing human dominance of tropical forests. Science, 349:827832. https://doi.org/10.1126/science.aaa9932

Lin Y, Hyyppa J, Jaakkola A (2011) Mini-UAV-borne LIDAR for fine-scale mapping. IEEE Geoscience and Remote Sensing Letters, 8:426-430.

Lisein J, Pierrot-Deseilligny M, Bonnet S, Lejeune P (2013) A photogrammetric workflow for the creation of a forest canopy height model from small unmanned aerial system imagery. Forests, 4:922-944. https://doi.org/10.3390/f4040922

Lu D, Chen Q, Wang G, Liu L, Li G, Moran E (2016) A survey of remote sensing-based aboveground biomass estimation methods in forest ecosystems. International Journal of Digital Earth, 9:63-105. https://doi.org/10.1080/17538947.2014.990526

Lucas R, Bunting P, Paterson M, Chisholm L (2008) Classification of Australian forest communities using aerial photography, CASI and HyMap data. Remote Sensing of Environment, 112:2088-2103. https://doi.org/10.1016/j.rse.2007.10.011 
Maeda EE, Heiskanen J, Thijs KW, Pellikka PK (2014) Season-dependence of remote sensing indicators of tree species diversity. Remote Sensing Letters, 5:404-412. https://doi.org/10.1080/2150704X.2014.912767

Main-Knorn M, Cohen WB, Kennedy RE, Grodzki W, Pflugmacher D, Griffiths P, Hostert P (2013) Monitoring coniferous forest biomass change using a Landsat trajectory-based approach. Remote Sensing of Environment, 139:277-290. https://doi.org/10.1016/j.rse.2013.08.010

Malhi Y, Phillips OL, Lloyd J, Baker T, Wright J, Almeida S, et al. (2002) An international network to monitor the structure, composition and dynamics of Amazonian forests (RAINFOR). Journal of Vegetation Science, 13:439-450. https://doi.org/10.1658/1100-9233(2002)013\%5B0439:AINTMT\%5D2.0.CO;2

Malhi Y, Román-Cuesta RM (2008) Analysis of lacunarity and scales of spatial homogeneity in IKONOS images of Amazonian tropical forest canopies. Remote Sensing of Environment, 112:2074-2087. https://doi.org/10.1016/j.rse.2008.01.009

Martin ME, Aber JD (1997) High spectral resolution remote sensing of forest canopy lignin, nitrogen, and ecosystem processes. Ecological Applications, 7:431-443. https://doi.org/10.1890/10510761(1997)007[0431:HSRRSO]2.0.CO;2

Mauya EW, Hansen EH, Gobakken T, Bollandsås OM, Malimbwi RE, Næsset E (2015) Effects of field plot size on prediction accuracy of aboveground biomass in airborne laser scanning-assisted inventories in tropical rain forests of Tanzania. Carbon Balance and Management, 10:10. https://doi.org/10.1186/s13021-015-0021-X

Medina O, Manian V, Chinea JD (2013) Biodiversity assessment using hierarchical agglomerative clustering and spectral unmixing over hyperspectral images. Sensors, 13:13949-13959. https://doi.org/10.3390/s131013949

Metzger JP, Martensen AC, Dixo M, Bernacci LC, Ribeiro MC, Teixeira AMG, Pardini R (2009) Time-lag in biological responses to landscape changes in a highly dynamic Atlantic forest region. Biological Conservation, 142:1166-1177. https://doi.org/10.1016/j.biocon.2009.01.033

Meyera P, Staenzb K, Ittena KI (1996) Semi-automated procedures for tree species identification in high spatial resolution data from digitized colour infrared-aerial photography. ISPRS Journal of Photogrammetry and Remote Sensing, 51:5-16. https://doi.org/10.1016/0924-2716(96)00003-2 
Michez A, Piégay H, Lisein J, Claessens H, Lejeune P (2016) Classification of riparian forest species and health condition using multi-temporal and hyperspatial imagery from unmanned aerial system. Environmental Monitoring and Assessment, 188:146. https://doi.org/10.1007/s10661-015-4996-2

Mulatu KA, Mora B, Kooistra L, Herold M (2017) Biodiversity Monitoring in Changing Tropical Forests: A Review of Approaches and New Opportunities. Remote Sensing, 9:1059. https://doi.org/10.3390/rs9101059

Myers N, Mittermeier RA, Mittermeier CG, Da Fonseca GA, Kent J (2000) Biodiversity hotspots for conservation priorities. Nature, 403:853-858. https://doi.org/10.1038/35002501

Næsset E (2002) Predicting forest stand characteristics with airborne scanning laser using a practical two-stage procedure and field data. Remote Sensing of Environment, 80:88-99. https://doi.org/10.1016/S00344257(01)00290-5

Nagendra H (2001) Using remote sensing to assess biodiversity. International Journal of Remote Sensing, 22:2377-2400. https://doi.org/10.1080/01431160117096

Nagendra H, Lucas R, Honrado JP, Jongman RH, Tarantino C, Adamo M, Mairota P (2013) Remote sensing for conservation monitoring: Assessing protected areas, habitat extent, habitat condition, species diversity, and threats. Ecological Indicators, 33:45-59. https://doi.org/10.1016/j.ecolind.2012.09.014

Nagendra H, Rocchini D (2008) High resolution satellite imagery for tropical biodiversity studies: the devil is in the detail. Biodiversity and Conservation, 17:3431-3442. https://doi.org/10.1007/s10531-008-9479-0

Nagendra H, Rocchini D, Ghate R, Sharma B, Pareeth S (2010) Assessing plant diversity in a dry tropical forest: Comparing the utility of Landsat and IKONOS satellite images. Remote Sensing, 2:478-496. https://doi.org/10.3390/rs2020478

Oldeland J, Wesuls D, Rocchini D, Schmidt M, Jürgens N (2010) Does using species abundance data improve estimates of species diversity from remotely sensed spectral heterogeneity? Ecological Indicators, 10:390-396. https://doi.org/10.1016/j.ecolind.2009.07.012

Orians GH, Dirzo R, Cushman JH (2012) Biodiversity and ecosystem processes in tropical forests (Vol. 122). Orians GH, Dirzo R, Cushman JH (eds). Springer Science and Business Media, Berlin. 
Ota T, Ogawa M, Mizoue N, Fukumoto K, Yoshida S (2017) Forest Structure Estimation from a UAV-Based Photogrammetric Point Cloud in Managed Temperate Coniferous Forests. Forests, 8:343. https://doi.org/10.3390/f8090343

Palmer MW, Earls PG, Hoagland BW, White PS, Wohlgemuth T (2002) Quantitative tools for perfecting species lists. Environmetrics, 13:121-137. https://doi.org/10.1002/env.516

Peck M, Mariscal A, Padbury M, Cane T, Kniveton D, Chinchero MA (2012) Identifying tropical Ecuadorian Andean trees from inter-crown pixel distributions in hyperspatial aerial imagery. Applied Vegetation Science, 15:548-559. https://doi.org/10.1111/j.1654-109X.2012.01196.x

Peres CA, Gardner TA, Barlow J, Zuanon J, Michalski F, Lees AC, Vieira ICG, Moreira FMS, Feeley KJ (2010) Biodiversity conservation in human-modified Amazonian forest landscapes. Biological Conservation, 143:2314:2327. https://doi.org/10.1016/j.biocon.2010. 01.021

Pettorelli N, Safi K, Turner W (2014) Satellite remote sensing, biodiversity research and conservation of the future. Philosophical Transactions of the Royal Society B: Biological Sciences, 369:1643. https://doi.org/10.1098/rstb.2013.0190

Phillips OL, Aragão LE, Lewis SL, Fisher JB, Lloyd J, López-González G, et al. (2009) Drought sensitivity of the Amazon rainforest. Science, 323:1344-1347. https://doi.org/10.1126/science.116403

Phillips OL, Vargas PN, Monteagudo AL, Cruz AP, Zans MEC, Sánchez WG, Yli-Halla M, Rose S (2003a) Habitat association among Amazonian tree species: a landscape-scale approach. Journal of Ecology, 91:757-775. https://doi.org/10.1046/j.1365-2745.2003.00815.x

Phillips OL, Vasquez Martinez R, Nunez Vargas P, Lorenzo Monteagudo A, Chuspe Zans ME, Galiano Sanchez W, Pena Cruz A, Timana M, Yli-Halla M, Rose S (2003b) Efficient plot-based floristic assessment of tropical forests. Journal of Tropical Ecology, 19:629-645. https://doi.org/10.1017/S0266467403006035

Ploton P, Pélissier R, Proisy C, Flavenot T, Barbier N, Rai SN, Couteron P (2012) Assessing aboveground tropical forest biomass using Google Earth canopy images. Ecological Applications, 22:993-1003. https://doi.org/10.1890/11-1606.1 
Proisy C, Couteron P, Fromard F (2007) Predicting and mapping mangrove biomass from canopy grain analysis using Fourier-based textural ordination of IKONOS images. Remote Sensing of Environment, 109:379-392. https://doi.org/10.1016/j.rse.2007.01.009

Ranta P, Blom TOM, Niemela J, Joensuu E, Siitonen M (1998) The fragmented Atlantic rain forest of Brazil: size, shape and distribution of forest fragments. Biodiversity and Conservation, 7(3):385-403. https://doi.org/10.1023/A:1008885813543

Read JM, Clark DB, Venticinque EM, Moreira MP (2003) Application of merged 1-m and 4-m resolution satellite data to research and management in tropical forests. Journal of Applied Ecology, 40:592-600. https://doi.org/10.1046/j.1365-2664.2003.00814.x

Robinson TP, Wardell-Johnson GW, Pracilio G, Brown C, Corner R, Van Klinken RD (2016) Testing the discrimination and detection limits of WorldView-2 imagery on a challenging invasive plant target. International Journal of Applied Earth Observation and Geoinformation, 44:23-30. https://doi.org/10.1016/j.jag.2015.07.004

Rocchini D (2007) Effects of spatial and spectral resolution in estimating ecosystem $\alpha$-diversity by satellite imagery. Remote Sensing of Environment, 111:423-434. https://doi.org/10.1016/j.rse.2007.03.018

Rocchini D, Balkenhol N, Carter GA, Foody GM, Gillespie TW, He KS, Kark S, Levin N, Lucas K, Luoto M, Nagendra H, Oldeland J, Ricotta C, Southworth J, Neteler M (2010) Remotely sensed spectral heterogeneity as a proxy of species diversity: recent advances and open challenges. Ecological Informatics, 5:318-329. https://doi.org/10.1016/j.ecoinf.2010.06.001

Rocchini D, Hernández-Stefanoni JL, He KS (2015) Advancing species diversity estimate by remotely sensed proxies: a conceptual review. Ecological Informatics, 25:22-28. https://doi.org/10.1016/j.ecoinf.2014.10.006

Rocchini D, Vannini A (2010) What is up? Testing spectral heterogeneity versus NDVI relationship using quantile regression. International Journal of Remote Sensing, 31:2745-2756. https://doi.org/10.1080/01431160903085651

Rosa IM, Smith MJ, Wearn OR, Purves D, Ewers RM (2016) The environmental legacy of modern tropical deforestation. Current Biology, 26(16):2161-2166. https://doi.org/10.1016/j.cub.2016.06.013 
Roth KL, Roberts DA, Dennison PE, Peterson SH, Alonzo M (2015) The impact of spatial resolution on the classification of plant species and functional types within imaging spectrometer data. Remote sensing of environment, 171:45-57. https://doi.org/10.1016/j.rse.2015.10.004

Rutishauser E, Wagner F, Herault B, Nicolini EA, Blanc L (2010) Contrasting above-ground biomass balance in a Neotropical rain forest. Journal of Vegetation Science, 21:672-682. https://doi.org/10.1111/j.16541103.2010.01175.x

Saari H, Pellikka I, Pesonen L, Tuominen S, Heikkilä J, Holmlund C, Mäkynen J, Ojala K, Antila T (2011) Unmanned Aerial Vehicle (UAV) operated spectral camera system for forest and agriculture applications. Proc. SPIE 8174, Remote Sensing for Agriculture, Ecosystems, and Hydrology XIII, 81740H (6 October 2011). https://doi.org/10.1117/12.897585

Saatchi SS, Harris NL, Brown S, Lefsky M, Mitchard ET, Salas W, et al. (2011) Benchmark map of forest carbon stocks in tropical regions across three continents. Proceedings of the National Academy of Sciences, 108:9899-9904. https://doi.org/10.1073/pnas.1019576108

Sader SA, Waide RB, Lawrence WT, Joyce AT (1989) Tropical forest biomass and successional age class relationships to a vegetation index derived from Landsat TM data. Remote Sensing of Environment, 28:143-198. https://doi.org/10.1016/0034-4257(89)90112-0

Schäfer E, Heiskanen J, Heikinheimo V, Pellikka P (2016) Mapping tree species diversity of a tropical montane forest by unsupervised clustering of airborne imaging spectroscopy data. Ecological Indicators, 64:49-58. https://doi.org/10.1016/j.ecolind.2015.12.026

Segura M, Kanninen M (2005) Allometric models for tree volume and total aboveground biomass in a tropical humid forest in Costa Rica. Biotropica, 37:2-8. https://doi.org/10.1111/j.1744-7429.2005.02027.x

Seidel D, Fleck S, Leuschner C, Hammett T (2011) Review of ground-based methods to measure the distribution of biomass in forest canopies. Annals of Forest Science, 68:225-244. https://doi.org/10.1007/s13595-011-0040-z

Slik JW, Paoli G, McGuire K, Amaral I, Barroso J, Bastian M, et al. (2013) Large trees drive forest aboveground biomass variation in moist lowland forests across the tropics. Global Ecology and Biogeography, 22:1261-1271. https://doi.org/10.1111/geb.12092 
Small C (2004) The Landsat ETM+ spectral mixing space. Remote Sensing of Environment, 93:1-17. https://doi.org/10.1016/j.rse.2004.06.007

Song C, Chen JM, Hwang T, Gonsamo A, Croft H, Zhang Q, Dannenberg M, Zhang Y, Hakkenberg C, Li J (2015) Ecological characterization of vegetation using multisensor remote sensing in the solar reflective spectrum. Land Resources Monitoring, Modeling, and Mapping with Remote Sensing; Thenkabail, PS, Ed, 533575.

Song C, Woodcock CE (2002) The spatial manifestation of forest succession in optical imagery: the potential of multiresolution imagery. Remote Sensing of Environment, 82:271-284. https://doi.org/10.1016/S00344257(02)00045-7

Stavros EN, Schimel D, Pavlick R, Serbin S, Swann A, Duncanson L, Fisher JB, Fassnacht F, Ustin S, Dubayah R, Schweiger A, Wennberg P (2017) ISS observations offer insights into plant function. Nature Ecology and Evolution, 1(7). https://doi.org/ 10.1038/s41559-017-0194

Steininger MK (2000) Satellite estimation of tropical secondary forest above-ground biomass: data from Brazil and Bolivia. International Journal of Remote Sensing, 21:1139-1157. https://doi.org/10.1080/014311600210119

Steinmann K, Mandallaz D, Ginzler C, Lanz A (2013) Small area estimations of proportion of forest and timber volume combining Lidar data and stereo aerial images with terrestrial data. Scandinavian Journal of Forest Research, 28:373-385. https://doi.org/10.1080/02827581.2012.754936

Strand H, Höft R, Strittholt J, Miles L, Horning N, Fosnight E, Turner W (2007) Sourcebook on Remote Sensing and Biodiversity Indicators, CBD Technical Series No. 32. Secretariat of the Convention on Biological Diversity, Montreal, Canada.

Stropp J, Ter Steege H, Malhi Y (2009) Disentangling regional and local tree diversity in the Amazon. Ecography, 32:46-54. https://doi.org/10.1111/j.1600-0587.2009.05811.x

Taubert F, Fischer R, Groeneveld J, Lehmann S, Müller MS, Rödig E, Wiegand T, Huth A (2018) Global patterns of tropical forest fragmentation. Nature, 554:519-522. https://doi.org/10.1038/nature25508

Ticehurst C, Held A, Phinn S (2004) Integrating JERS-1 imaging radar and elevation models for mapping tropical vegetation communities in Far North Queensland, Australia. Photogrammetric Engineering and Remote Sensing, 70:1259-1266. https://doi.org/10.14358/PERS.70.11.1259 
Tilman D, May RM, Lehman CL, Nowak MA (1994) Habitat destruction and the extinction debt. Nature, 371:65-66. https://doi.org/10.1038/371065a0

Townsend AR, Asner GP, Cleveland CC (2008) The biogeochemical heterogeneity of tropical forests. Trends in Ecology and Evolution, 23:424-431. https://doi.org/10.1016/j.tree.2008.04.009

Tuomisto H (2011) A diversity of beta diversities: straightening up a concept gone awry. Part 1. Defining beta diversity as a function of alpha and gamma diversity. Ecography, 33:2-22.

Turner MG (1989) Landscape ecology: the effect of pattern and process. Annual Review of Ecology and Systematics, 20:171-197. https://doi.org/10.1146/annurev.es.20.110189.001131

Turner IM, Corlett RT (1996) The conservation value of small, isolated fragments of lowland tropical rain forest. Trends in Ecology and Evolution, 11(8):330-333. https://doi.org/10.1016/0169-5347(96)10046-X

Turner W, Spector S, Gardiner N, Fladeland M, Sterling E, Steininger M (2003) Remote sensing for biodiversity science and conservation. Trends in Ecology and Evolution, 18:306-314. https://doi.org/10.1016/S01695347(03)00070-3

Valencia R, Balslev H, Miño GPY (1994) High tree alpha-diversity in Amazonian Ecuador. Biodiversity and Conservation, 3:21-28. https://doi.org/10.1007/BF00115330

van Coillie F, Delaplace K, Gabriels D, De Smet K, Ouessar M, Belgacem AO, Taamallah H, De Wulf R (2016) Monotemporal assessment of the population structure of Acacia tortilis (Forssk.) Hayne ssp. raddiana (Savi) Brenan in Bou Hedma National Park, Tunisia: A terrestrial and remote sensing approach. Journal of Arid Environments, 129:80-92. https://doi.org/10.1016/j.jaridenv.2016.02.009

Vellend M, Verheyen K, Jacquemyn H, Kole A, Van Calster A, Perterken G, Hermy M (2006) Extinction debt of forest plants persists for more than a century following habitat fragmentation. Ecology, 87:542-548. https://doi.org/10.1890/05-1182

Vincent G, Sabatier D, Rutishauser E (2014) Revisiting a universal airborne light detection and ranging approach for tropical forest carbon mapping: scaling-up from tree to stand to landscape. Oecologia, 175:439-443. https://doi.org/10.1007/s00442-014-2913-y 
Wallace L, Lucieer A, Watson C, Turner D (2012) Development of a UAV-LiDAR system with application to forest inventory. Remote Sensing, 4:1519-1543. https://doi.org/10.3390/rs4061519

Wang L, Sousa WP, Gong P, Biging GS (2004) Comparison of IKONOS and QuickBird images for mapping mangrove species on the Caribbean coast of Panama. Remote Sensing of Environment, 91:432-440. https://doi.org/10.1016/j.rse.2004.04.005

Wang G, Zhang M, Gertner GZ, Oyana T, McRoberts RE, Ge H (2011) Uncertainties of mapping aboveground forest carbon due to plot locations using national forest inventory plot and remotely sensed data. Scandinavian Journal of Forest Research, 26:360-373. https://doi.org/10.1080/02827581.2011.564204

Wilson SD (2000) Heterogeneity, diversity and scale in plant communities. In: Hutchings, M.J., John, E.A., Stewart, A.J.A. (Eds.). The ecological consequences of environmental heterogeneity. Blackwell Science, Oxford, pp. 53-69.

Wulder MA, Hall RJ, Coops NC, Franklin SE (2004) High spatial resolution remotely sensed data for ecosystem

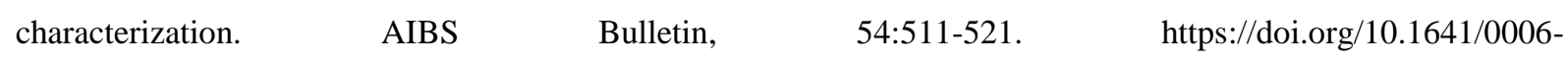
3568(2004)054[0511:HSRRSD]2.0.CO;2

Wulder MA, White JC, Nelson RF, Næsset E, Ørka HO, Coops NC, Hilker T, Bater CW, Gobakken T (2012) Lidar sampling for large-area forest characterization: A review. Remote Sensing of Environment, 121, $196-209$. https://doi.org/10.1016/j.rse.2012.02.001

Zarco-Tejada PJ, Diaz-Varela R, Angileri V, Loudjani P (2014) Tree height quantification using very high resolution imagery acquired from an unmanned aerial vehicle (UAV) and automatic 3D photo-reconstruction methods. European Journal of Agronomy, 55:89-99. https://doi.org/10.1016/j.eja.2014.01.004

Zarco-Tejada PJ, Guillén-Climent ML, Hernández-Clemente R, Catalina A, González MR, Martín P (2013) Estimating leaf carotenoid content in vineyards using high resolution hyperspectral imagery acquired from an unmanned aerial vehicle (UAV). Agricultural and Forest Meteorology, 171:281-294. https://doi.org/10.1016/j.agrformet.2012.12.013 